\title{
Pandangan Pengguna Penyata Kewangan terhadap Kepentingan Item di dalam Indeks Pelaporan Kewangan Menerusi Internet di Malaysia
}

\author{
Mohd Noor Azli Ali Khan ${ }^{\mathrm{a}^{*}}$, Noor Azizi Ismail ${ }^{\mathrm{b}}$ \\ a Jabatan Perakaunan dan Kewangan, Fakulti Pengurusan, Universiti Teknologi Malaysia 81310 UTM Johor Bahru, Johor, Malaysia \\ ${ }^{b}$ Othman Yeop Abdullah Graduate School of Business, Univerisiti Utara Malaysia, 06010 UUM Sintok, Kedah, Malaysia \\ *Corresponding author: m-nazli@utm.my
}

\section{Article history}

Received :1 August 2012

Received in revised form : 19

February 2013

Accepted : 28 February 2013

\begin{abstract}
This study investigates the perceptions of users of financial statement regarding the importance of items in indices of internet financial reporting (IFR). This study adopts the questionnaire survey method in order to seek the view of users of financial statement, particularly on the importance of items that to be included in the checklist of IFR indices. From a comprehensive review of the IFR literature, the level of IFR in this study can be categorized into two dimensions namely the 'content' and 'presentation'. The findings show that the five most important items which are income statement of current year, cash flow statement of current year, balance sheet of current year, annual report of current year (full text), and auditor report of current year can explain the dimension of content. Meanwhile, the five most important items for the dimension of presentation which are annual report in PDF format, loading time of the website, link to homepage, hyperlinks inside the annual report, and link to table of contents. Results of the study also provide empirical evidence that 144 disclosure items can be used for the checklist of IFR indices to measure the level of IFR. The finding provides an insight into the IFR practice in Malaysia. Implications of these findings and future research directions are also discussed in this study.
\end{abstract}

Keywords: Users; indices; weighted score; internet financial reporting; Malaysia

\begin{abstract}
Abstrak
Kajian ini cuba meneliti pandangan pengguna penyata kewangan berkaitan kepentingan item dalam indeks pelaporan kewangan menerusi Internet (PKMI). Kajian ini menggunakan kaedah tinjauan soal selidik untuk mengetahui pandangan pengguna penyata kewangan berhubung kepentingan item yang perlu terkandung dalam senarai semakan indeks PKMI. Berdasarkan sorotan karya yang menyeluruh, tahap PKMI dalam kajian ini dibahagikan kepada dua dimensi iaitu kandungan dan pembentangan. Penemuan kajian menunjukkan lima item terpenting iaitu penyata pendapatan tahun semasa, penyata aliran tunai tahun semasa, kunci kira-kira tahun semasa, laporan tahunan (teks penuh) tahun semasa, dan laporan juruaudit tahun semasa yang berupaya menggambarkan dimensi kandungan. Manakala, bagi dimensi pembentangan pula terdapat lima item terpenting daripada laporan tahunan dalam format PDF, masa muat turun laman web syarikat (kurang 10 saat), pautan kepada laman web utama, hiperpautan ada di dalam laporan tahunan, dan pautan kepada senarai kandungan. Penemuan kajian ini juga memberikan bukti empirikal bahawa 144 item pelaporan boleh digunakan bagi senarai semakan indeks PKMI untuk mengetahui tahap PKMI. Hasil kajian ini menyumbang kepada pemahaman tambahan tentang PKMI di Malaysia. Implikasi hasil kajian dan arah tuju penyelidikan masa hadapan turut dibincangkan.
\end{abstract}

Kata kunci: Pengguna; indeks; skor wajaran; pelaporan kewangan menerusi Internet; Malaysia

(c) 2013 Penerbit UTM Press. All rights reserved.

\subsection{PENGENALAN}

Internet mewujudkan satu persekitaran pelaporan yang baru di dalam menyampaikan maklumat korporat bagi syarikat tersenarai yang mempunyai keinginan secara berterusan berkomunikasi dengan para pemegang saham sedia ada dan untuk menarik bakal pelabur (Boubaker et al., 2012). Kewujudan laman web syarikat menjadi medium yang penting bagi tujuan pelaporan korporat
(Trabelsi et al., 2004; Ismail \& Sobhy, 2009), laman web dimanafaatkan oleh syarikat untuk memberitahu maklumat korporat kepada para pelabur di seluruh dunia (Abdelsalam \& Street, 2007; AbuGhazaleh et al., 2012) dan mempromosikan identiti korporat (Poon et al., 2003; Topalian, 2003). Laman web syarikat turut digunakan untuk tujuan menyampaikan maklumat mengenai organisasi dan aktivitinya (Chan \& Wickramasinghe, 2006; Sriram \& Laksmana 2006) serta menyampaikan maklumat 
kewangan kepada pemegang saham, pelabur dan pihak lain yang berkepentingan (Hodge \& Pronk, 2006; Abdelsalam \& El-Masry, 2008). Teknologi World Wide Web (WWW) atau jaringan sejagat digunakan dengan meluas melalui peningkatan bilangan syarikat di seluruh dunia yang mempunyai laman web korporat (Celik et al., 2006; Boubaker et al., 2012). WWW merupakan sebahagian daripada Internet dan popularitinya meningkat sejak dua dekad yang lalu disebabkan oleh laman web korporat dilihat sebagai medium komunikasi yang murah, dinamik dan sentiasa berkembang (Ettredge et al., 2001). Dalam konteks perakaunan, laman web merupakan medium alternatif yang sangat penting bagi penyebaran maklumat korporat termasuk laporan tahunan (Khan 2006; Chan \& Wickramasinghe, 2006; Sriram \& Laksamana, 2006). Walau bagaimanapun, tahap penggunaan teknologi bagi praktis pelaporan kewangan menerusi Internet (PKMI) didapati berbeza-beza di kalangan negara (Oyelere et al., 2003).

Sebarang perubahan dalam sistem komunikasi akan memberi impak yang besar dan cabaran yang hebat bukan sahaja kepada syarikat dan regulator tetapi juga akauntan. Salah satu cabaran penting yang berkaitan kualiti maklumat yang dipersembahkan dalam laman web korporat ialah ketiadaan garis panduan yang dikeluarkan oleh regulator (Seetharaman \& Subramaniam, 2006). Seetharaman dan Subramaniam (2006) menyatakan masih belum ada peraturan dan piawaian berkaitan penyebaran maklumat menerusi laman web daripada mana-mana badan profesional atau agensi kerajaan. Keadaan ini menyebabkan kualiti dan kandungan PKMI adalah berbeza-beza di antara syarikat. PKMI masih bersifat sukarela tanpa sebarang perundangan atau garis panduan bagi mengawal dan menjelaskan maklumat yang disampaikan dengan cara yang komprehensif (Ashbaugh et al., 1999; Bonson \& Escobar, 2002; Marston \& Polei, 2004; Hanifa \& Ab. Rashid, 2005; Momany \& Shorman, 2006; Kelton \& Yang, 2008; Ismail \& Sobhy, 2009; Homayoun et al., 2011; Boubaker et al., 2012). Sehingga kini, Lembaga Piawaian Perakaunan Malaysia (LPPM) atau Malaysian Accounting Standards Board (MASB) masih belum mengeluarkan sebarang piawaian perakaunan atau garis panduan berkaitan PKMI untuk terma bagi kandungan dan pembentangan maklumat di dalam laman web syarikat. Namun begitu, PKMI menjadi mandatori bagi kesemua syarikat di Turki yang mempunyai laman web dan disenaraikan di Bursa Saham Istanbul mulai 2005 (Bozcuk, 2012).

Kebanyakan kajian PKMI di Malaysia adalah berbentuk deskriptif yang meliputi isu seperti jenis maklumat yang dilaporkan (Ismail \& Tayib, 2000), pengelasan pembangunan web ke atas pelaporan kewangan (Keliwon \& Aziz, 2005), perbezaan praktis PKMI di antara Malaysia dengan Singapura (Khadaroo, 2005a), praktis PKMI dan kesannya pada pengauditan (Khadaroo, 2005b), maklumat hubungan dengan pelabur (Abdul Hamid, 2005), penggunaan Internet bagi hubungan dengan pelabur oleh syarikat Malaysia dan Singapura (Abdul Hamid et al., 2006), serta kandungan dan aplikasi reka bentuk laman web syarikat (Mohamad et al., 2006). Terdapat juga beberapa kajian penjelasan dijalankan seperti faktor penentu yang mempengaruhi PKMI (Hassan et al., 1999; Abdul Hamid \& Md Salleh, 2005; Hanifa \& Ab. Rashid, 2005; Ali Khan, 2010) dan faktor penentu bagi pelaporan kewangan dan persekitaran menerusi Internet oleh syarikat yang tersenarai di Bursa Malaysia (Al Arussi et al., 2009).

Walaupun pelbagai kajian berkaitan PKMI telah dijalankan sama ada di negara membangun dan sedang membangun, namun masih wujud persoalan yang memerlukan kajian lanjutan. Kajian lanjutan perlu dilakukan bagi mendapatkan bukti empirikal berhubung isu PKMI berasaskan kepada sifat kajian PKMI yang dinamik. Antara persoalan yang timbul ialah apakah item yang sesuai yang dapat digunakan bagi mengukur tahap PKMI di
Malaysia. Setakat ini, isu berkaitan item pelaporan yang perlu ada di dalam indeks PKMI menurut pandangan pengguna penyata kewangan amat terhad. Oleh itu, kajian ini mengambil inisiatif untuk mengkaji indeks PKMI dengan mengambil kira pandangan pengguna penyata kewangan bagi mengetahui tahap PKMI. Seterusnya, keadaan ini merupakan jurang yang cuba dipenuhi oleh kajian ini. Kepentingan kajian ini disokong oleh ulasan karya lepas yang mendapati kajian yang mengambil kira pandangan pengguna penyata kewangan berkaitan PKMI masih kurang dipelopori (Al-Htaybat et al., 2011; Ali Khan \& Ismail, 2012c). Pandangan pengguna penyata kewangan diperlukan dalam kajian ini kerana mereka terdedah dengan maklumat perakaunan dan mempunyai pengetahuan serta kemahiran untuk menggunakan maklumat yang terkandung dalam laporan tahunan (Mohd Isa, 2006) dan kumpulan pengguna memerlukan sumber maklumat bagi proses pembuatan keputusan (Al-Htaybat et al., 2011). Justeru, objektif kajian ini untuk mendapatkan bukti empirikal tentang sejauhmana kepentingan item pelaporan berdasarkan pandangan pengguna penyata kewangan yang boleh digunakan untuk menerangkan tahap PKMI dalam kalangan syarikat yang tersenarai di Bursa Malaysia. Impak penerokaan kajian yang disusuli oleh pembuktian secara empirikal ini berupaya untuk menyumbang kepada badan ilmu berkaitan penyelidikan PKMI.

Artikel ini disusun seperti berikut. Bahagian kedua membincangkan ulasan karya berkaitan PKMI. Ini diikuti oleh metodologi yang digunakan. Bahagian seterusnya pula akan membincangkan penemuan kajian. Akhir sekali, kesimpulan dan cadangan kajian dihuraikan dalam bahagian kelima.

\subsection{ULASAN KARYA}

Internet muncul sebagai platform komunikasi pilihan bagi penyebaran maklumat kewangan dan perniagaan di kalangan syarikat korporat bermula sekitar tahun 1990-an. Selaras dengan perkembangan teknologi Internet yang bermula pada awal tahun 1990-an, penyelidikan pelaporan perakaunan turut berkembang dan merangkumi kajian berhubung PKMI.

PKMI merupakan bidang penyelidikan yang baru dan luas untuk diselidiki (Moradi, Salehi \& Arianpoor, 2011), agenda penyelidikan perakaunan kewangan yang penting bagi kajian pada masa hadapan (Ali Khan \& Ismail, 2011a; Ali Khan \& Ismail, 2012a) dan menjadi satu tumpuan penyelidikan di peringkat antarabangsa (Al-Htaybat, 2011). Ulasan karya berkaitan PKMI dan isu komunikasi mula diterbitkan sejak tahun 1997 atau 1998 (Gowthorpe, 2004). Terdapat peningkatan yang mendadak dalam penggunaan Internet bagi tujuan penyebaran maklumat korporat (Boubaker et al., 2012). Walau bagaimanapun, kajian awal berkaitan PKMI adalah bersifat deskriptif (Allam \& Lymer, 2003).

Penelitian terhadap kajian berkaitan PKMI sepanjang dua dekad yang lalu mendapati hanya sedikit sahaja kajian yang memberi fokus kepada pembinaan indeks pelaporan bagi menerangkan fenomena PKMI ini dengan lebih baik. Kaedah yang digunakan bagi membina indeks pelaporan ini pula didapati berbeza-beza dalam kalangan penyelidik. Sehubungan dengan itu, satu kajian yang lebih menyeluruh bagi mencari kaedah pembinaan indeks pelaporan yang lebih tepat adalah perlu. Ini disebabkan kepentingan penggunaan indeks pelaporan bagi tujuan perbandingan praktis PKMI antara syarikat, industri dan negara.

Isu berkaitan pendekatan pembinaan indeks yang digunakan bagi menilai tahap PKMI mempunyai dua pandangan berbeza iaitu (1) pendekatan wajaran atau pemberat, dan (2) pendekatan bukan wajaran atau tiada pemberat. Jadual 1 menunjukkan beberapa kajian terkini berkaitan pengukuran tahap PKMI. Berdasarkan penelitian terhadap kajian-kajian lepas, penyelidik 
mendapati bahawa terdapat sedikit usaha dalam kalangan ahli sarjana yang menggunakan pendekatan wajaran untuk mengetahui tahap PKMI terutamanya daripada pandangan pengguna penyata kewangan. Penyelidik turut mendapati bahawa kebanyakan kajian lepas menggunakan pendekatan bukan wajaran untuk mengetahui tahap PKMI. Seperkara lagi, pengunaan item yang dinilai atau dimensi yang digunakan dalam kalangan penyelidik untuk mengukur tahap PKMI turut tidak konsisten (Ali Khan \& Ismail, 2009b). Hal yang sedemikian membuka ruang perdebatan berhubung penggunaan skala pengukuran dan dimensi bagi mengukur tahap PKMI. Namun begitu, Ali Khan dan Ismail (2009b) mencadangkan penggunaan dimensi kandungan dan dimensi pembentangan untuk mengetahui tahap PKMI bagi syarikat yang tersenarai di Bursa Malaysia. Penggunaan dimensi kandungan dan pembentangan dalam kajian PKMI telah dibincangkan dengan terperinci dalam kajian Ali Khan dan Ismail (2009b). Menurut Ali Khan dan Ismail (2009b), dimensi kandungan akan memberikan maklumat mengenai jenis maklumat yang dilaporkan oleh syarikat menerusi laman web. Manakala, dimensi pembentangan pula akan memberikan maklumat mengenai penggunaan ciri paparan terkini dalam menyebarkan maklumat korporat dan reka bentuk laman web sesebuah syarikat.

Jadual 1 Beberapa kajian terkini berkaitan pengukuran tahap PKMI

\begin{tabular}{|c|c|c|c|c|}
\hline Tahun & Penyelidik & Skop Kajian & Skala Pengukuran & Item yang dinilai \\
\hline 2006 & Chan dan Wickramasinghe & Australia & $\begin{array}{l}\text { - Senarai semakan: Skor } 1 \text { (Item } \\
\text { dilaporkan), Skor } 0 \text { (Item tidak } \\
\text { dilaporkan) }\end{array}$ & $\begin{array}{l}\text { - Kandungan } \\
\text { - Ketepatan masa } \\
\text { - Teknologi } \\
\text { - Sokongan pengguna }\end{array}$ \\
\hline 2007 & Abdelsalam, Bryant dan Street & UK & $\begin{array}{l}\text { - Senarai semakan: Skor } 1 \text { (Item } \\
\text { dilaporkan), Skor } 0 \text { (Item tidak } \\
\text { dilaporkan) }\end{array}$ & $\begin{array}{l}\text { - Kandungan } \\
\text { - Usability }\end{array}$ \\
\hline 2008 & $\begin{array}{l}\text { Mohd Hanafi, Kasim, Ibrahim dan } \\
\text { Othman }\end{array}$ & Malaysia & $\begin{array}{l}\text { - Tiada pemberat } \\
\text { - Pemberat }\end{array}$ & $\begin{array}{l}\text { - Reka bentuk laman web } \\
\text { - Kandungan laman web }\end{array}$ \\
\hline 2008 & Ezat dan El-Masry & Egypt & $\begin{array}{l}\text { - Senarai semakan: Skor } 1 \text { (Item } \\
\text { dilaporkan), Skor } 0 \text { (Item tidak } \\
\text { dilaporkan) }\end{array}$ & - Pemasaan \\
\hline 2008 & Kelton dan Yang & US & $\begin{array}{l}\text { - Senarai semakan: Skor } 1 \text { (Item } \\
\text { dilaporkan), Skor } 0 \text { (Item tidak } \\
\text { dilaporkan) }\end{array}$ & $\begin{array}{l}\text { - Kandungan } \\
\text { - Pembentangan }\end{array}$ \\
\hline 2008 & Abdelsalam dan El-Masry & Ireland & $\begin{array}{l}\text { - Senarai semakan: Skor } 1 \text { (Item } \\
\text { dilaporkan), Skor } 0 \text { (Item tidak } \\
\text { dilaporkan) }\end{array}$ & - Pemasaan \\
\hline 2009 & Al Arussi, Selamat dan Mohd Hanefah & Malaysia & $\begin{array}{l}\text { - Senarai semakan: Skor } 2 \text { (syarikat } \\
\text { melaporkan lebih daripada } 2 \text { item), Skor } \\
1 \text { (syarikat melaporkan 1-2 item), Skor } \\
0 \text { (Tiada pelaporan) }\end{array}$ & $\begin{array}{l}\text { - Kewangan } \\
\text { - Persekitaran }\end{array}$ \\
\hline 2009 & Despina dan Demetrios & Greek & $\begin{array}{l}\text { - Senarai semakan: Skor } 1 \text { (Item } \\
\text { dilaporkan), Skor } 0 \text { (Item tidak } \\
\text { dilaporkan) }\end{array}$ & $\begin{array}{l}\text { - Kewangan } \\
\text { - Maklumat tadbir urus korporat } \\
\text { - Hubungan dengan pelabur } \\
\text { - Tanggungjawab sosial korporat } \\
\text { - Pembentangan }\end{array}$ \\
\hline 2009 & $\begin{array}{l}\text { Mohd Hanafi, Kasim, Ibrahim dan } \\
\text { Hancock }\end{array}$ & $\begin{array}{l}\text { US, UK, } \\
\text { Malaysia, } \\
\text { Singapura \& } \\
\text { Thailand }\end{array}$ & $\begin{array}{l}\text { - Tiada pemberat } \\
\text { - Pemberat }\end{array}$ & $\begin{array}{l}\text { - Reka bentuk laman web } \\
\text { - Kandungan laman web }\end{array}$ \\
\hline 2010 & Aly, Simon dan Hussainey & Egypt & $\begin{array}{l}\text { - Senarai semakan: Skor } 1 \text { (Item } \\
\text { dilaporkan), Skor } 0 \text { (Item tidak } \\
\text { dilaporkan) }\end{array}$ & $\begin{array}{l}\text { - Kandungan } \\
\text { - Pembentangan }\end{array}$ \\
\hline 2010 & Ali Khan & Malaysia & $\begin{array}{l}\text { - Senarai semakan: Skor } 1 \text { (Item } \\
\text { dilaporkan), Skor } 0 \text { (Item tidak } \\
\text { dilaporkan) }\end{array}$ & $\begin{array}{l}\text { - Kandungan } \\
\text { - Pembentangan }\end{array}$ \\
\hline 2011 & Al-Htaybat & Jordan & $\begin{array}{l}\text { - Senarai semakan: Skor } 1 \text { (Item } \\
\text { dilaporkan), Skor } 0 \text { (Item tidak } \\
\text { dilaporkan) }\end{array}$ & $\begin{array}{l}\text { - Pembentangan dan kecapaian } \\
\text { - Maklumat korporat kewangan dan } \\
\text { bukan-kewangan }\end{array}$ \\
\hline 2011 & Pervan dan Sabljic & Crotia & $\begin{array}{l}\text { - Senarai semakan: Skor } 1 \text { (Item } \\
\text { dilaporkan), Skor } 0 \text { (Item tidak } \\
\text { dilaporkan) }\end{array}$ & $\begin{array}{l}\text { - Kewangan } \\
\text { - Maklumat tadbir urus korporat } \\
\text { - Hubungan dengan pelabu } \\
\text { - Pendedahan sosial korporat } \\
\text { - Pembentangan }\end{array}$ \\
\hline 2011 & Henchiri & $\begin{array}{l}\text { Morroco dan } \\
\text { Tunisia }\end{array}$ & $\begin{array}{l}\text { - Senarai semakan: Skor } 1 \text { (Item } \\
\text { dilaporkan), Skor } 0 \text { (Item tidak } \\
\text { dilaporkan) }\end{array}$ & $\begin{array}{l}\text { - Maklumat am } \\
\text { - Maklumat bukan-kewangan } \\
\text { - Maklumat kewangan } \\
\text { - Reka bentuk laman web }\end{array}$ \\
\hline 2011 & Erer & Turki & $\begin{array}{l}\text { - Senarai semakan: Skor } 1 \text { (Item } \\
\text { dilaporkan), Skor } 0 \text { (Item tidak } \\
\text { dilaporkan) }\end{array}$ & $\begin{array}{l}\text { - Format } \\
\text { - Kandungan }\end{array}$ \\
\hline
\end{tabular}




\begin{tabular}{|c|c|c|c|c|}
\hline Tahun & Penyelidik & Skop Kajian & Skala Pengukuran & Item yang dinilai \\
\hline 2012 & Ali Khan dan Ismail & Malaysia & $\begin{array}{l}\text { - Senarai semakan: Skor } 1 \text { (Item } \\
\text { dilaporkan), Skor } 0 \text { (Item tidak } \\
\text { dilaporkan) }\end{array}$ & $\begin{array}{l}\text { - Kandungan } \\
\text { - Pembentangan }\end{array}$ \\
\hline 2012 & Boubaker, Lakhal dan Nekhili & Perancis & $\begin{array}{l}\text { - Senarai semakan: Skor } 1 \text { (Item } \\
\text { dilaporkan), Skor } 0 \text { (Item tidak } \\
\text { dilaporkan) }\end{array}$ & $\begin{array}{l}\text { - Maklumat am } \\
\text { - Maklumat kewangan } \\
\text { - Maklumat tadbir urus korporat, dan } \\
\text { tanggungjawab sosial dan korporat }\end{array}$ \\
\hline 2012 & Bozcuk & Turki & $\begin{array}{l}\text { - Senarai semakan: Skor } 1 \text { (Item } \\
\text { dilaporkan), Skor } 0 \text { (Item tidak } \\
\text { dilaporkan) }\end{array}$ & - Pembentangan \\
\hline 2012 & Malhotra dan Makkar & India & $\begin{array}{l}\text { - Senarai semakan: Skor } 1 \text { (Item } \\
\text { dilaporkan), Skor } 0 \text { (Item tidak } \\
\text { dilaporkan) }\end{array}$ & $\begin{array}{l}\text { - Artibut am } \\
\text { - Artibut kewangan }\end{array}$ \\
\hline 2012 & Nurunnabi dan Hossain & Bangladesh & $\begin{array}{l}\text { - Senarai semakan: Skor } 1 \text { (Item } \\
\text { dilaporkan), Skor } 0 \text { (Item tidak } \\
\text { dilaporkan) }\end{array}$ & $\begin{array}{l}\text { - Kandungan penyata kewangan } \\
\text { - Maklumat kewangan lain } \\
\text { - Pembentangan dan sokongan } \\
\text { pengguna }\end{array}$ \\
\hline
\end{tabular}

Penggunaan dimensi kandungan dan pembentangan didorong oleh beberapa faktor utama. Pertama, dimensi kandungan dan pembentangan adalah dimensi yang paling popular dan kerap digunakan dalam kajian lalu (IASC, 1999; Debreceny et al., 2002; Marston \& Polei, 2004; Trabelsi et al., 2004; Xiao et al., 2004; Spanos, 2006; Bonson \& Escobar, 2006; Kelton \& Yang, 2008; Aly et al., 2010; Ali Khan, 2010; Ali Khan \& Ismail, 2012b). Kedua, kajian terdahulu menunjukkan bahawa format kandungan dan pembentangan bagi pelaporan Internet boleh memperbaiki ketelusan pelaporan (Hodge et al., 2004; Kelton \& Yang, 2005). Ketiga, PKMI membenarkan penyebaran alternatif bagi jenis pelaporan yang tidak diperlukan oleh badan berperaturan (regulatory bodies) (Ettredge et al., 2002). Keempat, format pembentangan boleh menyediakan pelaporan yang lebih telus melalui peningkatan kebolehbacaan, mudah diperoleh, mudah difahami bagi maklumat kewangan (FASB, 2000), membantu memperoleh maklumat dengan cepat serta disokong dengan penggunaan ciri paparan yang bersifat mesra pengguna dalam laman web (Marston \& Polei, 2004), berurusan dengan bagaimana maklumat itu dipersembahkan (Xiao et al., 2004), dan boleh memperbaiki ketepatan masa (peningkatan dalam kekerapan pelaporan) dan pengesahan (berupaya untuk menghubungkan dengan pelbagai sumber maklumat lain seperti hiperpautan) (Debreceny et al., 2002). Manakala, format kandungan boleh menunjukkan jenis maklumat yang dilaporkan oleh syarikat menerusi laman web (Lybaert, 2002; Xiao et al., 2004).

Kajian berkaitan kepentingan item PKMI turut mendapat perhatian, antaranya Ali Khan dan Ismail (2010) mengkaji kepentingan item PKMI menurut pandangan penyedia laporan tahunan menggunakan dimensi kandungan dan dimensi pembentangan bagi mengetahui tahap PKMI. Penyedia laporan tahunan dalam kajian ini terdiri daripada ketua pegawai kewangan dan akauntan bagi syarikat yang tersenarai di Pasaran Utama Bursa Malaysia. Hasil kajian menunjukkan bahawa terdapat lima item utama iaitu penyata pendapatan tahun semasa, kunci kira-kira tahun semasa, nota penyata kewangan tahun semasa, penyata pendapatan tahun lepas, dan penyata aliran tunai tahun semasa yang berupaya menggambarkan dimensi kandungan. Manakala, bagi dimensi pembentangan terdapat lima item utama iaitu masa muat turun laman sesawang syarikat, pautan kepada laman sesawang, hiperpautan kepada analisis kewangan, hiperpautan ada di dalam laporan tahunan, dan pautan kepada senarai kandungan.

Ali Khan dan Ismail (2011b) mengkaji tahap PKMI bagi syarikat yang tersenarai di Bursa Malaysia. Berdasarkan penelitian yang mendalam berkaitan penggunaan dimensi yang dapat menggambarkan tahap PKMI, tahap PKMI boleh diukur dengan menggunakan dua dimensi utama iaitu dimensi kandungan dan dimensi pembentangan. Dimensi kandungan akan memberikan maklumat mengenai jenis maklumat yang dilaporkan oleh syarikat menerusi laman dan dimensi pembentangan pula akan memberikan maklumat mengenai penggunaan ciri paparan terkini dalam menyebarkan maklumat korporat dan reka bentuk laman sesawang sesebuah syarikat (Ali Khan dan Ismail, 2009b). Hasil kajian menunjukkan bahawa purata tahap PKMI ialah 65.10 dengan nilai minimum dan maksimum masing-masing 48.27 peratus dan 78.16 peratus. Ini bermaksud secara purata tahap pelaporan berkaitan PKMI bagi syarikat yang tersenarai di Pasaran Utama Bursa Malaysia adalah berada pada tahap 65.10 peratus. Tahap pelaporan ini boleh dikategorikan sebagai tahap pelaporan yang baik sepertimana pengkelasan tahap pelaporan yang dibuat oleh Wallace (1988).

Ali Khan dan Ismail (2011c) mengulas sorotan literatur berkaitan penyelidikan PKMI. Hasil kajian menunjukkan bahawa penggunaan terma, dimensi dan pengklasifikasian berkaitan PKMI tidak konsisten dalam kalangan penyelidik. Perbezaan ini menyumbang kepada perbezaan dapatan kajian dan seterusnya gagal menerangkan dengan jelas faktor penentu yang mempengaruhi PKMI. Penelitian terhadap kajian PKMI turut mendapati sedikit sahaja kajian yang memberi fokus kepada pembinaan indeks pelaporan bagi menerangkan tahap PKMI. Pengajaran yang dapat dicungkil daripada perbincangan dan ulasan hal tersebut ialah perlunya satu kajian yang lebih komprehensif bagi membincangkan isu berkaitan PKMI.

Kajian terkini oleh kajian Ali Khan dan Ismail (2012b) mengenai indeks PKMI menurut pandangan penyedia penyata kewangan menunjukkan bahawa terdapat 87 item pelaporan yang boleh digunakan dalam senarai semakan PKMI untuk 
mengetahui tahap PKMI di kalangan syarikat tersenarai di Bursa Malaysia. Hasil kajian turut menunjukkan bahawa terdapat lima item utama iaitu penyata pendapatan tahun semasa, kunci kirakira tahun semasa, penyata aliran tunai tahun semasa, laporan juruaudit tahun semasa dan laporan tahunan (teks penuh) tahun semasa yang berupaya menggambarkan dimensi kandungan. Manakala, bagi dimensi pembentangan terdapat lima item utama iaitu masa muat turun laman web syarikat (kurang 10 saat), laporan tahunan dalam format PDF, hiperpautan kepada analisis kewangan, hiperpautan ada di dalam laporan tahunan, dan pautan kepada laman sesawang utama.

Kebanyakan kajian lalu dalam bidang PKMI lebih bersifat deskriptif, perbandingan dan penjelasan (Ali Khan \& Ismail, 2011c). Usaha yang dijalankan oleh pengkaji terdahulu untuk mendapatkan pandangan penyedia penyata kewangan dalam pembinaan senarai semakan indeks PKMI adalah amat terhad (Ali Khan, 2010; Ali Khan \& Ismail, 2010; Ali Khan \& Ismail, 2012b). Kajian lalu membentuk indeks PKMI dengan hanya berpandukan kepada indeks yang telah dibentuk oleh pengkaji terdahulu sahaja. Keunikan indeks PKMI dalam kajian ini disebabkan oleh pembentukan indeks yang mengambil kira input daripada kajian lepas, pandangan ahli akademik, pengamal industri dan pandangan pengguna penyata kewangan. Justeru, hasil kajian ini amat penting kerana ianya berupaya untuk menyumbangkan bukti secara empirikal kepada sorotan literatur berkaitan item pelaporan yang perlu ada dalam senarai semakan indeks PKMI.

\subsection{REKA BENTUK KAJIAN}

Terdapat dua teknik utama yang digunakan untuk menentukan tahap PKMI iaitu sistem penskoran bukan wajaran (Ashbaugh et al., 1999; Bonson \& Escobar, 2002; Debreceny et al., 2002; Allam \& Lymer, 2003; Oyelere et al., 2003; Bonson \& Escobar, 2006; Celik et al., 2006; Chan \& Wickramasinghe, 2006; Abdelsalam et al., 2007; Kelton \& Yang, 2008; Al Arussi et al., 2009; Mohd Hanafi et al., 2009; Aly et al., 2010; Homayoun et al., 2011; Ali Khan \& Ismail, 2012b; Boubaker et al., 2012; Bozcuk, 2012; Malhotra \& Makkar, 2012; Nurunnabi \& Hossain, 2012; Uyar, 2012) dan sistem penskoran wajaran (Davey \& Homkajohn, 2004; Marston \& Polei, 2004; Mohd Hanafi et al., 2008; Mohd Hanafi et al., 2009). Teknik sistem penskoran bukan wajaran merupakan yang paling popular digunakan bagi mengetahui tahap PKMI. Sepanjang kajian dilakukan, penyelidik mendapati bahawa kajian yang menggunakan sistem penskoran wajaran bagi mengetahui tahap PKMI adalah amat terhad. Kajian ini menggunakan pendekatan sistem penskoran wajaran bagi memberi sumbangan kepada kajian literatur yang sedia ada. Malahan, Inchausti (1997) menyatakan bahawa sistem penskoran wajaran membenarkan darjah kepentingan bagi setiap item pelaporan dinilai. Oleh itu, penulis berpendapat bahawa kaedah ini lebih tepat bagi mengetahui tahap kepentingan item pelaporan untuk mengetahui tahap PKMI. Kajian ini juga menggunakan pendekatan kajian tinjauan berasaskan soal selidik bagi mengetahui tahap kepentingan item PKMI mengikut pandangan pengguna penyata kewangan.

\subsection{Sampel Kajian}

Dalam kajian ini, terdapat empat kumpulan sasaran pengguna penyata kewangan iaitu pelajar universiti di peringkat prasiswazah, ahli akademik di institusi pengajian tinggi awam (IPTA), pengurus atau pemilik entiti perniagaan dan pegawai bank di sektor swasta. Pandangan daripada pengguna penyata kewangan (broker saham, remiser, pemilik perniagaan, pelajar universiti, ahli akademik dan lain-lain pengguna) terdedah dengan maklumat perakaunan dan mempunyai pengetahuan yang diperlukan untuk menggunakan maklumat yang terkandung dalam laporan tahunan (Mohd Isa, 2006). Kumpulan pengguna penyata kewangan (penganalisis kewangan, ahli akademik, pegawai kredit bank dan juruaudit) memerlukan sumber maklumat bagi proses pembuatan keputusan (AlHtaybat et al., 2011). Pelajar universiti di peringkat prasiswazah dipilih kerana mereka dipercayai akan menjadi pengguna penyata kewangan berasaskan kepada latar belakang pengkhususan bidang akademik (Mohd Isa, 2006). Hodge (2001) menyatakan bahawa pelajar universiti dalam bidang perniagaan mempunyai karakter yang sama dengan peniaga dalam talian dan pelajar sarjana perniagaan digunakan sebagai proksi bagi peniaga dalam talian. Dalam kajian ini, pelajar sarjana muda perakaunan daripada Fakulti Pengurusan dan Pembangunan Sumber Manusia (FPPSM), Universiti Teknologi Malaysia telah dipilih sebagai responden kajian. Kumpulan ini dipercayai akan menjadi pengguna penyata kewangan disebabkan latar belakang pengajian akademik (Mohd Isa, 2006).

Pemilihan ahli akademik di IPTA sebagai sampel kerana mereka menggunakan maklumat perakaunan untuk pengajaran dan berkemungkinan mereka juga merupakan pemegang saham (Jaafar et al., 2010). Ahli akademik turut dipilih sebagai sampel dalam kajian Mohd Isa (2006) kerana mereka terlibat dalam proses pengajaran dan pembelajaran bagi kursus yang menggunakan laporan tahunan sebagai sebahagian alat pengajaran seperti perakaunan kewangan, analisis pelaburan dan kewangan. Mishekary dan Saudagaran (2005) memilih ahli akademik sebagai proksi bagi pengguna penyata kewangan kerana mereka bertanggungjawab dalam pengajian perakaunan bersesuaian dengan hasrat kerajaan untuk melahirkan akauntan profesional. Pengurus atau pemilik entiti perniagaan dipilih sebagai responden kajian kerana mereka boleh dipertimbangkan sebagai pihak yang membuat keputusan harian dan keputusan tersebut memberi kesan kepada proses perniagaan (Barsky \& Catanach, 2011). Manakala, pegawai bank di sektor swasta turut dipilih sebagai responden kajian Mishekary dan Saudagaran (2005) kerana mereka mewakili ekonomi pasaran.

\subsection{Pembinaan Item}

Kajian lepas berkaitan faktor penentu bagi PKMI telah membina indeks pelaporan untuk mengkaji perhubungan dengan karakter spesifik syarikat (Debreceny et al., 2002; Oyelere et al., 2003; Xiao et al., 2004; Bonson \& Escobar, 2006; Abdelsalam et al., 2007; Barako et al., 2008; Al Arussi et al., 2009; Ali Khan, 2010; Aly et al., 2010; Al-Htaybat, 2011; Boubaker et al., 2012; Bozcuk, 2012; Nurunnabi \& Hossain, 2012; Uyar, 2012). Namun begitu, kajian lepas tidak mengambil kira pandangan pengguna penyata kewangan terhadap item pelaporan dalam pembentukan indeks PKMI. Oleh yang demikian, kajian ini dilaksanakan dengan mengambil kira pandangan pengguna penyata kewangan dalam pembinaan indeks PKMI.

Pelaporan kewangan merupakan satu konsep abstrak yang tidak dapat diukur secara terus. Proksi yang bersesuaian seperti indeks pelaporan boleh digunakan untuk menentukan maklumat yang dilaporkan oleh sesebuah syarikat (Cooke \& Wallace, 1989). Oleh itu, salah satu tugas yang penting dalam kajian ini melibatkan pemilihan item maklumat yang dilaporkan di dalam laman web syarikat yang tersenarai di Papan Utama Bursa Malaysia bagi mengetahui tahap PKMI. Justeru, pendekatan broad-based (lihat Haniffa, 1999) digunakan di dalam pemilihan item yang dimasukkan dalam senarai semakan. 
Menurut Sekaran (2003), broad problem area merujuk kepada situasi keseluruhan yang mana kelihatan satu kemungkinan keperluan untuk dilakukan kajian dan mencari jalan penyelesaian.

Menurut Curuk (2008), terdapat tiga perkara dalam prosedur bagi pembinaan indeks pelaporan iaitu pembinaan lembaran skor pelaporan, pengiraan skor item pelaporan dan pembinaan indeks pelaporan. Memandangkan tiada teori umum yang boleh digunakan berkaitan bilangan dan pemilihan item yang perlu dimasukkan di dalam indeks pelaporan (Wallace, 1988; Wallace et al., 1994; Haniffa, 1999), kajian lalu berkaitan indeks PKMI dijadikan panduan iaitu bilangan item bermula daripada 11 item (Abdelsalam \& Street, 2007; Ezat \& El-Masry, 2008) hingga 205 item (Mohd Hanafi et al., 2009). Langkah yang dilakukan dalam pembinaan item senarai semakan bagi indeks PKMI sama seperti Haniffa (1999), Ali Khan dan Ismail (2010), dan Ali Khan dan Ismail (2012b).

\subsection{Kutipan Data}

Data bagi kajian ini dikutip melalui soal selidik yang dihantar melalui pos. Setiap responden menerima soal selidik yang mempunyai kod (bagi tujuan semakan dan penjejakan) bersamasama dengan surat yang menyatakan tujuan kajian dan maklumat yang diberikan oleh responden adalah sulit. Responden disertakan sampul surat beralamat sendiri dan bersetem.

Soal selidik telah dihantar kepada 390 responden (iaitu ahli akademik, pelajar universiti, pengurus eksekutif dan pegawai bank) dengan menggunakan persampelan bertujuan. Persampelan bertujuan sesuai digunakan ke atas kumpulan sasaran tertentu (Ayob (2005). Hasilnya, sejumlah 268 soal selidik telah dipulangkan dengan kadar maklum balas sebanyak $68.72 \%$ (rujuk Jadual 2). Tahap maklum balas ini dianggap mencukupi berasaskan kepada fakta kadar maklum balas purata bagi kajian kaedah tinjauan menggunakan kaedah pos di Malaysia adalah di sekitar 10 hingga 16 peratus (PricewaterhouseCoopers, 2002) dan ianya lebih tinggi daripada kadar maklum balas yang memadai dalam lingkungan 15 ke 20 peratus bagi kaedah tinjauan soal selidik (Standen, 1998). Kadar maklum balas ini memadai dalam kajian ini kerana ianya melebihi dengan beberapa kajian terdahulu iaitu 14 peratus $(\mathrm{Ku}$ Ismail \& Chandler, 2005), 13.29 peratus (Mohd Isa, 2006), 10.30 peratus (Leng et al., 2007), 15.10 peratus (Gibbins et al., 2007), 14.40 peratus (Ku Ismail \& Chandler, 2007) dan 15.11 peratus (Ali Khan, 2010). Frazer dan Lawley (2000) pula menyatakan bahawa keputusan banyak kajian yang menggunakan soal selidik menunjukkan kadar maklum balas seperti $10 \%$ atau kurang. Soal selidik mempunyai beberapa bahagian. Bahagian pertama berkaitan tahap kepentingan item pelaporan bagi dimensi kandungan dan bahagian kedua berkaitan tahap kepentingan item pelaporan bagi dimensi pembentangan. Manakala, bahagian ketiga berkaitan profil responden dan pandangan pengguna berkaitan kepelbagaian isu PKMI. Skala likert 5 mata digunakan dalam pengukuran soal selidik yang mana 1 mewakili sangat tidak penting dan 5 bermaksud sangat penting.
Jadual 2 Taburan responden

\begin{tabular}{clll}
\hline No. & Kumpulan Pengguna & Maklum Balas & \\
\hline 1 & Ahli akademik & $34 / 50=68 \%$ & \\
2 & Pelajar universiti & $74 / 80=93 \%$ & \\
3 & Pengurus eksekutif & $106 / 150=67 \%$ & \\
4 & Pegawai bank & $54 / 110=49 \%$ & \\
\hline & Jumlah & $\mathbf{2 6 8}$ responden daripada $\mathbf{3 9 0}=$ \\
& & $\mathbf{6 8 . 7 2 \%}$ & \\
\hline
\end{tabular}

Oppenheim (1992) mencadangkan bahawa salah satu cara yang praktikal untuk mengesan bias tidak respons ialah dengan membuat perbandingan respons di antara responden yang memberi maklum balas awal dengan responden yang memberi maklum balas lewat. Perbandingan ke atas item yang terkandung dalam dimensi kandungan dan dimensi pembentangan telah dilakukan. Hasil kajian mendapati bahawa nilai min yang diuji tidak menunjukkan nilai min yang terlalu berbeza di antara kumpulan responden yang memberi maklum balas awal dengan kumpulan responden yang memberi maklum balas lewat. Seterusnya, berdasarkan ujian t bagi dua sampel bebas didapati terdapat sedikit perbezaan yang signifikan dari segi maklum balas yang diberikan di antara kumpulan responden yang memberi maklum balas awal dengan kumpulan responden yang memberi maklum balas lewat. Oleh itu, keduadua kumpulan tersebut boleh digabungkan sebagai satu sampel.

\subsection{PENEMUAN DAN PERBINCANGAN}

Berdasarkan Jadual 3 daripada 268 orang responden, jumlah lelaki ialah 119 orang yang mewakili 44.4 peratus dan jumlah perempuan seramai 149 yang mewakili 55.6 peratus. Di samping itu, perbezaan umur menunjukkan perbezaan yang agak ketara antara satu sama lain seperti 30 tahun dan kurang seramai 147 yang mewakili 54.9 peratus, diikuti 31 hingga 40 tahun seramai 75 orang yang mewakili 28 peratus, 41 hingga 50 tahun seramai 34 orang mewakili 12.7 peratus dan bilangan yang sedikit dicatatkan pada usia 51 hingga 60 tahun seramai 12 orang mewakili 4.4 peratus sahaja. Bagi jawatan dalam organisasi menunjukkan responden yang terdiri daripada ahli akademik mencatatkan seramai 34 orang yang mewakili 12.7 peratus. Seterusnya, seramai 74 orang terdiri daripada pelajar universiti yang mewakili 27.6 peratus. Diikuti dengan pegawai eksekutif seramai 106 orang yang mewakili 39.6 peratus dan pegawai bank yang terdiri daripada 54 orang yang mewakili 20.1 peratus

Jadual 3 Profil responden

\begin{tabular}{|l|l|c|c|}
\hline Perkara & Item & Kekerapan & Peratus (\%) \\
\hline \multirow{3}{*}{ Jantina } & Lelaki & 119 & 44.4 \\
\cline { 2 - 4 } & Perempuan & 149 & 55.6 \\
\hline \multirow{4}{*}{ Umur } & 30 tahun dan kurang & 147 & 54.9 \\
\cline { 2 - 4 } & 31 hingga 40 tahun & 75 & 28.0 \\
\cline { 2 - 4 } & 41 hingga 50 tahun & 34 & 12.7 \\
\cline { 2 - 4 } & 51 hingga 60 tahun & 12 & 4.4 \\
\hline \multirow{3}{*}{$\begin{array}{l}\text { Jawatan } \\
\text { organisasi }\end{array}$} & Ahli akademik & 34 & 12.7 \\
\cline { 2 - 4 } & Pelajar universiti & 74 & 27.6 \\
\cline { 2 - 4 } & Pegawai eksekutif & 106 & 39.6 \\
\cline { 2 - 4 } & Pegawai bank & 54 & 20.1 \\
\hline
\end{tabular}


Bagi menentukan tahap kepentingan item bagi dimensi kandungan, responden dikehendaki memberi maklum balas terhadap 97 item. Pandangan responden diukur dengan menggunakan skala likert 5 mata yang mana 1 mewakili sangat tidak penting dan 5 bermaksud sangat penting. Jadual 4 menunjukkan kepentingan item PKMI dalam dimensi kandungan dan diukur berdasarkan nilai min. Hasil kajian mendapati 92 item yang tersenarai dalam dimensi kandungan dikategorikan sebagai item yang penting (iaitu min melebihi 3.50) untuk menggambarkan tahap kepentingan dimensi kandungan dalam indeks PKMI. Nilai min bersamaan dengan 3.50 (sepertimana kajian Ho \& Wong, 2001; Ali Khan \& Ismail, 2008; Ali Khan \& Ismail, 2010; Ali Khan \& Ismail, 2012b) diguna pakai sebagai asas untuk melayakkan sesuatu item pelaporan itu disenaraikan dalam senarai semakan indeks PKMI. Ini kerana nilai min 3.50 merupakan nilai skala pengukuran di antara agak setuju dan setuju. Nilai min 3.50 mencukupi untuk menggambarkan tahap kepentingan sesuatu item pelaporan itu perlu dimasukkan dalam senarai semakan indeks PKMI.

Daripada 92 item tersebut, 25 item boleh dikategorikan sebagai item yang sangat penting (iaitu min melebihi 4.00). Manakala, daripada 97 item terdapat 25 item yang mencapai skor min pada tahap sangat penting yang mana sepuluh teratas terdiri daripada ialah penyata pendapatan tahun semasa $(\mathrm{min}=$ $4.39)$, penyata aliran tunai tahun semasa $(\min =4.36)$, kunci kira-kira tahun semasa (min 4.34), laporan tahunan (teks penuh) tahun semasa $(\min =4.32)$, laporan juruaudit tahun semasa $(\min$ $=4.29)$, nota penyata kewangan tahun semasa $(\min =4.24)$, penyata pendapatan tahun lepas $(\min =4.24)$, penyata aliran tunai tahun lepas $(\min =4.22)$, laporan tahunan (teks penuh) tahun lepas $(\min =4.22)$ dan kunci kira-kira tahun lepas $(\min =$ 4.18). Hasil kajian ini selari dengan dapatan kajian Ali Khan dan Ismail (2010) dan Ali Khan dan Ismail (2012b) yang menunjukkan bahawa item pelaporan penyata pendapatan tahun semasa merupakan item pelaporan yang paling penting bagi dimensi kandungan.

Manakala, 92 item yang tersenarai dalam dimensi kandungan dikategorikan sebagai item yang penting yang mana sepuluh daripadanya ialah ringkasan data kewangan penting lima tahun $(\min =3.97)$, harga saham historikal $(\min =3.97)$, pemegang saham 10 teratas tahun semasa $(\min =3.96)$, tandatangan CEO di dalam laporan $(\min =3.95)$, jualan produk utama (3.94), data kewangan terkini $(\min =3.94)$, laporan tahunan ringkasan tahun semasa (3.93), nisbah kewangan (3.91), ringkasan nisbah penting lima tahun (3.91) dan laporan segmen perniagaan tahun semasa.

Setelah mendapat maklum balas daripada pengguna penyata kewangan, sejumlah 92 item daripada 97 item dengan skor kepentingan minimum sebanyak 3.50 digunakan sebagai asas bagi mengukur indeks PKMI bagi dimensi kandungan.

Jadual 4 Pandangan keseluruhan kepentingan item bagi dimensi kandungan

\begin{tabular}{|c|c|c|c|c|c|c|c|c|c|c|c|c|c|}
\hline \multirow[t]{2}{*}{ Item Pelaporan } & \multicolumn{2}{|c|}{1} & \multicolumn{2}{|c|}{2} & \multicolumn{2}{|c|}{3} & \multicolumn{2}{|c|}{4} & \multicolumn{2}{|c|}{5} & \multirow[t]{2}{*}{ Min } & \multirow[t]{2}{*}{$\mathbf{K}$} & \multirow[t]{2}{*}{ S.P. } \\
\hline & No. & $\%$ & No. & $\%$ & No. & $\%$ & No. & $\%$ & No. & $\%$ & & & \\
\hline Penyata pendapatan tahun semasa & 0 & 0 & 3 & 1.1 & 24 & 9.0 & 107 & 39.9 & 134 & 50.0 & 4.39 & 1 & .697 \\
\hline Penyata aliran tunai tahun semasa & 0 & 0 & 5 & 1.9 & 22 & 8.2 & 112 & 41.8 & 129 & 48.1 & 4.36 & 2 & .713 \\
\hline Kunci kira-kira tahun semasa & 1 & .4 & 5 & 1.9 & 25 & 9.3 & 109 & 40.7 & 128 & 47.8 & 4.34 & 3 & .754 \\
\hline Laporan tahunan (teks penuh) tahun semasa & 0 & 0 & 5 & 1.9 & 28 & 10.4 & 110 & 41.0 & 125 & 46.6 & 4.32 & 4 & .736 \\
\hline Laporan juruaudit tahun semasa & 0 & 0 & 6 & 2.2 & 32 & 11.9 & 108 & 40.3 & 122 & 45.5 & 4.29 & 5 & .763 \\
\hline Nota penyata kewangan tahun semasa & 0 & 0 & 4 & 1.5 & 30 & 11.2 & 131 & 48.9 & 103 & 38.4 & 4.24 & 6 & .706 \\
\hline Penyata pendapatan tahun lepas & 0 & 0 & 4 & 1.5 & 36 & 13.4 & 120 & 44.8 & 108 & 40.3 & 4.24 & 7 & .736 \\
\hline Penyata aliran tunai tahun lepas & 0 & 0 & 3 & 1.1 & 38 & 14.2 & 125 & 46.6 & 102 & 38.1 & 4.22 & 8 & .723 \\
\hline Laporan tahunan (teks penuh) tahun lepas & 0 & 0 & 6 & 2.2 & 39 & 14.6 & 114 & 42.5 & 109 & 40.7 & 4.22 & 9 & .773 \\
\hline Kunci kira-kira tahun lepas & 0 & 0 & 5 & 1.9 & 43 & 16.0 & 119 & 44.4 & 101 & 37.7 & 4.18 & 10 & .763 \\
\hline Tandatangan juruaudit tahun semasa & 2 & .7 & 10 & 3.7 & 35 & 13.1 & 120 & 44.8 & 101 & 37.7 & 4.15 & 11 & .839 \\
\hline Penyata perubahan ekuiti & 0 & 0 & 8 & 3.0 & 42 & 15.7 & 126 & 47.0 & 92 & 34.3 & 4.13 & 12 & .778 \\
\hline Laporan juruaudit tahun lepas & 0 & 0 & 6 & 2.2 & 56 & 20.9 & 102 & 38.1 & 104 & 28.8 & 4.13 & 13 & .819 \\
\hline Maklumat dividen & 0 & 0 & 5 & 1.9 & 42 & 15.7 & 136 & 50.7 & 85 & 31.7 & 4.12 & 14 & .732 \\
\hline Polisi perakaunan & 0 & 0 & 7 & 2.6 & 52 & 19.4 & 111 & 41.4 & 98 & 36.6 & 4.12 & 15 & .808 \\
\hline Laporan/analisis pengurusan tahun semasa & 2 & .7 & 5 & 1.9 & 48 & 17.9 & 118 & 44.0 & 95 & 35.4 & 4.12 & 16 & .815 \\
\hline Laporan tahunan dalam versi English & 1 & .4 & 5 & 1.9 & 53 & 19.8 & 114 & 42.5 & 95 & 35.4 & 4.11 & 17 & .807 \\
\hline Analisis risiko perniagaan utama & 0 & 0 & 9 & 3.4 & 48 & 17.9 & 121 & 45.1 & 90 & 33.6 & 4.09 & 18 & .802 \\
\hline Asas Financial Reporting Standard tahun semasa & 0 & 0 & 4 & 1.5 & 57 & 21.3 & 120 & 44.8 & 87 & 32.5 & 4.08 & 19 & .770 \\
\hline Laman web versi English & 0 & 0 & 7 & 2.6 & 64 & 23.9 & 105 & 39.2 & 92 & 34.3 & 4.05 & 20 & .828 \\
\hline Perubahan ekuiti pemegang saham tahun semasa & 0 & 0 & 3 & 1.1 & 51 & 19.0 & 145 & 54.1 & 69 & 25.7 & 4.04 & 21 & .702 \\
\hline Tambahan atau pindaan laporan tahunan semasa & 0 & 0 & 8 & 3.0 & 50 & 18.7 & 133 & 49.6 & 77 & 28.7 & 4.04 & 22 & .771 \\
\hline $\begin{array}{l}\text { Pengguna boleh mendapatkan maklumat kewangan } \\
\text { dengan cepat }\end{array}$ & 0 & 0 & 5 & 1.9 & 59 & 22.0 & 124 & 46.3 & 80 & 29.9 & 4.04 & 23 & .771 \\
\hline Nota penyata kewangan tahun lepas & 0 & 0 & 11 & 4.1 & 49 & 18.3 & 125 & 46.6 & 83 & 31.0 & 4.04 & 24 & .811 \\
\hline
\end{tabular}




\begin{tabular}{|c|c|c|c|c|c|c|c|c|c|c|c|c|c|}
\hline \multirow[t]{2}{*}{ Item Pelaporan } & \multicolumn{2}{|c|}{$\mathbf{1}$} & \multicolumn{2}{|c|}{2} & \multicolumn{2}{|c|}{3} & \multicolumn{2}{|c|}{4} & \multicolumn{2}{|c|}{5} & \multirow[t]{2}{*}{ Min } & \multirow[t]{2}{*}{$\mathbf{K}$} & \multirow[t]{2}{*}{ S.P. } \\
\hline & No. & $\%$ & No. & $\%$ & No. & $\%$ & No. & $\%$ & No. & $\%$ & & & \\
\hline Tandatangan juruaudit tahun lepas & 1 & .4 & 18 & 6.7 & 40 & 14.9 & 127 & 47.7 & 82 & 30.6 & 4.01 & 25 & .872 \\
\hline $\begin{array}{l}\text { Maklumat tahun semasa dibezakan dengan tahun } \\
\text { lepas }\end{array}$ & 0 & 0 & 10 & 3.7 & 63 & 23.5 & 113 & 42.2 & 82 & 30.6 & 4.00 & 26 & .832 \\
\hline Ringkasan data kewangan penting lima tahun & 2 & .7 & 10 & 3.7 & 56 & 20.9 & 125 & 46.6 & 75 & 28.0 & 3.97 & 27 & .841 \\
\hline Harga saham historical & 0 & 0 & 26 & 9.7 & 81 & 30.2 & 123 & 45.9 & 38 & 14.2 & 3.96 & 28 & .811 \\
\hline Pemegang saham 10 teratas tahun semasa & 2 & .7 & 15 & 5.6 & 66 & 24.6 & 120 & 44.8 & 65 & 24.3 & 3.96 & 29 & .874 \\
\hline Tandatangan CEO di dalam laporan & 2 & .7 & 25 & 9.3 & 51 & 19.0 & 97 & 36.2 & 93 & 34.7 & 3.95 & 30 & .989 \\
\hline Jualan produk utama & 1 & .4 & 9 & 3.4 & 62 & 23.1 & 128 & 47.8 & 68 & 25.4 & 3.94 & 31 & .808 \\
\hline Data kewangan terkini & 1 & .4 & 10 & 3.7 & 61 & 22.8 & 127 & 47.4 & 69 & 25.7 & 3.94 & 32 & .817 \\
\hline Laporan tahunan ringkasan tahun semasa & 0 & 0 & 6 & 2.2 & 71 & 26.5 & 128 & 47.8 & 63 & 23.5 & 3.93 & 33 & .766 \\
\hline Nisbah kewangan & 2 & .7 & 10 & 3.7 & 62 & 23.1 & 130 & 48.5 & 64 & 23.9 & 3.91 & 34 & .825 \\
\hline Ringkasan nisbah penting lima tahun & 2 & .7 & 9 & 3.4 & 66 & 24.6 & 125 & 46.6 & 66 & 24.6 & 3.91 & 35 & .830 \\
\hline Laporan segmen perniagaan tahun semasa & 1 & .4 & 12 & 4.5 & 57 & 21.3 & 141 & 52.6 & 57 & 21.3 & 3.90 & 36 & .794 \\
\hline Pautan kepada laman web Bursa Malaysia & 0 & 0 & 7 & 2.6 & 78 & 29.1 & 118 & 44.0 & 65 & 24.3 & 3.90 & 37 & .794 \\
\hline Bilangan saham yang diniagakan & 0 & 0 & 12 & 4.5 & 68 & 25.4 & 124 & 46.3 & 64 & 23.9 & 3.90 & 38 & .814 \\
\hline $\begin{array}{l}\text { Prestasi harga saham berhubung dengan indeks } \\
\text { pasaran stok }\end{array}$ & 0 & 0 & 7 & 2.6 & 67 & 25.0 & 142 & 53.0 & 52 & 19.4 & 3.89 & 39 & .734 \\
\hline Maklumat pelan pelaburan semula dividen & 1 & .4 & 10 & 3.7 & 68 & 25.4 & 129 & 48.1 & 60 & 22.4 & 3.88 & 40 & .806 \\
\hline Maklumat pegangan saham pengarah & 0 & 0 & 15 & 5.6 & 67 & 25.0 & 121 & 45.1 & 65 & 24.3 & 3.88 & 41 & .840 \\
\hline $\begin{array}{l}\text { Petunjuk bagi mendapatkan maklumat semasa } \\
\text { secara terus }\end{array}$ & 1 & .4 & 8 & 3.0 & 74 & 27.6 & 128 & 47.8 & 57 & 21.3 & 3.87 & 42 & .791 \\
\hline Alamat syarikat (format HTML) & 1 & .4 & 10 & 3.7 & 72 & 26.9 & 124 & 46.3 & 61 & 22.8 & 3.87 & 43 & .816 \\
\hline Laporan setengah tahun bagi tahun semasa & 0 & 0 & 13 & 4.9 & 69 & 25.7 & 129 & 48.1 & 57 & 21.3 & 3.86 & 44 & .804 \\
\hline Maklumat korporat & 0 & 0 & 15 & 5.6 & 73 & 27.2 & 123 & 45.9 & 57 & 21.3 & 3.83 & 45 & .826 \\
\hline Laporan tahunan (petikan) tahun semasa & 1 & .4 & 16 & 6.0 & 70 & 26.1 & 122 & 45.5 & 59 & 22.0 & 3.83 & 46 & .853 \\
\hline Maklumat strategi korporat & 0 & 0 & 13 & 4.9 & 73 & 27.2 & 131 & 48.9 & 51 & 19.0 & 3.82 & 47 & .792 \\
\hline Sebut harga saham & 1 & .4 & 12 & 4.5 & 73 & 27.2 & 129 & 48.1 & 53 & 19.8 & 3.82 & 48 & .809 \\
\hline Maklumat mesyuarat agung tahunan & 1 & .4 & 17 & 6.3 & 73 & 27.2 & 114 & 42.5 & 63 & 23.5 & 3.82 & 49 & .876 \\
\hline Graf harga saham & 2 & .7 & 16 & 6.0 & 66 & 24.6 & 130 & 48.5 & 54 & 20.1 & 3.81 & 50 & .849 \\
\hline Laporan segmen zon tahun semasa & 1 & .4 & 17 & 6.3 & 76 & 28.4 & 117 & 43.7 & 57 & 21.3 & 3.79 & 51 & .862 \\
\hline Maklumat tarikh terkini laman web dikemas kini & 3 & 1.1 & 25 & 9.3 & 69 & 25.7 & 99 & 36.9 & 72 & 26.9 & 3.79 & 52 & .980 \\
\hline Pengkelasan saham & 0 & 0 & 19 & 7.1 & 68 & 25.4 & 135 & 50.4 & 46 & 17.2 & 3.78 & 53 & .813 \\
\hline Piagam bagi jawatankuasa audit & 0 & 0 & 16 & 6.0 & 78 & 29.1 & 125 & 46.6 & 49 & 18.3 & 3.77 & 54 & .814 \\
\hline $\begin{array}{l}\text { Masa kemas kini yang spesifik bagi pelaporan data } \\
\text { harga saham/stok }\end{array}$ & 3 & 1.1 & 19 & 7.1 & 60 & 22.4 & 140 & 52.2 & 46 & 17.2 & 3.77 & 55 & .855 \\
\hline $\begin{array}{l}\text { Soalan lazim atau Frequently Asked Question } \\
\text { (FAQ) }\end{array}$ & 1 & .4 & 10 & 3.7 & 88 & 32.8 & 123 & 45.9 & 46 & 17.2 & 3.76 & 56 & .791 \\
\hline Ahli lembaga pengarah & 1 & .4 & 19 & 7.1 & 73 & 27.2 & 126 & 47.0 & 49 & 18.3 & 3.76 & 57 & .846 \\
\hline Resolusi mesyuarat pemegang saham tahun semasa & 1 & .4 & 23 & 8.6 & 75 & 28.0 & 108 & 40.3 & 61 & 22.8 & 3.76 & 58 & .912 \\
\hline Resolusi lembaga pengarah tahun semasa & 0 & 0 & 18 & 6.7 & 75 & 28.0 & 131 & 48.9 & 44 & 16.4 & 3.75 & 59 & .808 \\
\hline Laporan segmen perniagaan tahun lepas & 2 & .7 & 13 & 4.9 & 86 & 32.1 & 117 & 43.7 & 50 & 18.7 & 3.75 & 60 & .841 \\
\hline Laporan pengerusi & 0 & 0 & 22 & 8.2 & 81 & 30.2 & 107 & 39.9 & 58 & 21.6 & 3.75 & 61 & .887 \\
\hline Harga saham setiap bulan & 1 & .4 & 22 & 8.2 & 70 & 26.1 & 128 & 47.8 & 47 & 17.5 & 3.74 & 62 & .856 \\
\hline Piagam syarikat tahun semasa & 0 & 0 & 21 & 7.8 & 80 & 29.9 & 115 & 42.9 & 52 & 19.4 & 3.74 & 63 & .861 \\
\hline Laporan sukuan tahun semasa & 0 & 0 & 27 & 10.1 & 71 & 26.5 & 115 & 42.9 & 55 & 20.5 & 3.74 & 64 & .899 \\
\hline Laporan tahunan (petikan) tahun lepas & 1 & .4 & 21 & 7.8 & 79 & 29.5 & 116 & 43.3 & 51 & 19.0 & 3.73 & 65 & .872 \\
\hline Maklumat pemegang saham & 0 & 0 & 27 & 10.1 & 72 & 26.9 & 115 & 42.9 & 54 & 20.1 & 3.73 & 66 & .897 \\
\hline $\begin{array}{l}\text { Laman web selain English (contoh Bahasa } \\
\text { Melayu) }\end{array}$ & 1 & .4 & 25 & 9.3 & 80 & 29.9 & 103 & 38.4 & 59 & 22.0 & 3.72 & 67 & .923 \\
\hline
\end{tabular}




\begin{tabular}{|c|c|c|c|c|c|c|c|c|c|c|c|c|c|}
\hline \multirow[t]{2}{*}{ Item Pelaporan } & \multicolumn{2}{|c|}{1} & \multicolumn{2}{|c|}{2} & \multicolumn{2}{|c|}{3} & \multicolumn{2}{|c|}{4} & \multicolumn{2}{|c|}{5} & \multirow[t]{2}{*}{ Min } & \multirow[t]{2}{*}{$\mathbf{K}$} & \multirow[t]{2}{*}{ S.P. } \\
\hline & No. & $\%$ & No. & $\%$ & No. & $\%$ & No. & $\%$ & No. & $\%$ & & & \\
\hline $\begin{array}{l}\text { Alamat surat menyurat kepada hubungan dengan } \\
\text { pelabur }\end{array}$ & 0 & 0 & 24 & 9.0 & 82 & 30.6 & 110 & 41.0 & 52 & 19.4 & 3.71 & 68 & .881 \\
\hline Maklumat yang dijangkakan & 3 & 1.1 & 19 & 7.1 & 80 & 29.9 & 117 & 43.7 & 49 & 18.3 & 3.71 & 69 & .885 \\
\hline Kalendar bagi aktiviti kewangan akan datang & 2 & .7 & 18 & 6.7 & 80 & 29.9 & 127 & 47.4 & 41 & 15.3 & 3.70 & 70 & .836 \\
\hline Kenyataan penafian atau disclaimer & 1 & .4 & 13 & 4.9 & 91 & 34.0 & 125 & 46.6 & 38 & 14.2 & 3.69 & 71 & .786 \\
\hline $\begin{array}{l}\text { Petunjuk maklumat diaudit dan tidak diaudit } \\
\text { (sukuan dan setengah tahun) }\end{array}$ & 1 & .4 & 16 & 6.0 & 90 & 33.6 & 118 & 44.0 & 43 & 16.0 & 3.69 & 72 & .823 \\
\hline Laporan segmen zon tahun lepas & 2 & .7 & 19 & 7.1 & 87 & 32.5 & 112 & 41.8 & 48 & 17.9 & 3.69 & 73 & .873 \\
\hline Laporan tanggungjawab sosial korporat & 0 & 0 & 20 & 7.5 & 86 & 32.1 & 122 & 45.5 & 40 & 14.9 & 3.68 & 74 & .817 \\
\hline Laporan setengah tahun bagi tahun lepas & 0 & 0 & 27 & 10.1 & 79 & 29.5 & 116 & 43.3 & 46 & 17.2 & 3.68 & 75 & .876 \\
\hline Resolusi lembaga penyeliaan tahun semasa & 1 & .4 & 20 & 7.5 & 87 & 32.5 & 119 & 44.4 & 41 & 15.3 & 3.67 & 76 & .838 \\
\hline Maklumat modal intelek & 2 & .7 & 23 & 8.6 & 75 & 28.0 & 129 & 48.1 & 39 & 14.6 & 3.67 & 77 & .855 \\
\hline $\begin{array}{l}\begin{array}{l}\text { Maklumat para } \\
\text { eksekutif) }\end{array} \\
\text { pengurus }\end{array}$ & 2 & .7 & 28 & 10.4 & 79 & 29.5 & 107 & 39.9 & 52 & 19.4 & 3.67 & 78 & .931 \\
\hline Nombor telefon kepada hubungan dengan pelabur & 0 & 0 & 27 & 10.1 & 79 & 29.5 & 119 & 44.4 & 43 & 16.0 & 3.66 & 79 & .865 \\
\hline Harga saham semasa & 0 & 0 & 13 & 4.9 & 54 & 20.1 & 131 & 48.9 & 70 & 26.1 & 3.65 & 80 & .842 \\
\hline $\begin{array}{l}\text { Maklumat pandangan pihak ketiga mengenai } \\
\text { syarikat }\end{array}$ & 3 & 1.1 & 21 & 7.8 & 91 & 34.0 & 104 & 38.8 & 49 & 18.3 & 3.65 & 81 & .905 \\
\hline Maklumat pegangan saham pekerja & 2 & .7 & 32 & 11.9 & 66 & 24.6 & 126 & 47.0 & 42 & 15.7 & 3.65 & 82 & .910 \\
\hline $\begin{array}{l}\text { Kod kelakuan dan etika bagi para pengarah, } \\
\text { pegawai dan pekerja }\end{array}$ & 1 & .4 & 33 & 12.3 & 77 & 28.7 & 108 & 40.3 & 49 & 18.3 & 3.64 & 83 & .932 \\
\hline $\begin{array}{l}\text { Pilihan e-mel berkaitan siaran akhbar, newsletters } \\
\text { dsbnya }\end{array}$ & 2 & .7 & 16 & 6.0 & 97 & 36.2 & 118 & 44.0 & 35 & 13.1 & 3.63 & 84 & .813 \\
\hline E-mel kepada hubungan dengan pelabur & 0 & 0 & 25 & 9.3 & 91 & 34.0 & 109 & 40.7 & 43 & 16.0 & 3.63 & 85 & .862 \\
\hline Sidang/siaran akhbar atau berita semasa & 1 & .4 & 20 & 7.5 & 94 & 35.1 & 118 & 44.0 & 35 & 13.1 & 3.62 & 86 & .819 \\
\hline $\begin{array}{l}\text { Kalendar bagi aktiviti yang diminati kepada para } \\
\text { pelabur }\end{array}$ & 1 & .4 & 30 & 11.2 & 77 & 28.7 & 124 & 46.3 & 36 & 13.4 & 3.61 & 87 & .869 \\
\hline $\begin{array}{l}\text { Jualan atau data pengoperasian bulanan atau } \\
\text { mingguan }\end{array}$ & 3 & 1.1 & 23 & 8.6 & 89 & 33.2 & 115 & 42.9 & 38 & 14.2 & 3.60 & 88 & .874 \\
\hline Senarai penganalisis mengikut firma & 0 & 0 & 23 & 8.6 & 96 & 35.8 & 117 & 43.7 & 32 & 11.9 & 3.59 & 89 & .809 \\
\hline Prinsip atau garis panduan tadbir urus korporat & 0 & 0 & 31 & 11.6 & 86 & 21.1 & 116 & 43.3 & 35 & 13.1 & 3.58 & 90 & .860 \\
\hline Laporan sukuan tahun lepas & 1 & .4 & 41 & 15.3 & 74 & 27.6 & 112 & 41.8 & 40 & 14.9 & 3.56 & 91 & .936 \\
\hline Resolusi lembaga pengarah tahun lepas & 0 & 0 & 31 & 11.6 & 94 & 35.1 & 113 & 42.2 & 30 & 11.2 & 3.53 & 92 & .841 \\
\hline Resolusi lembaga penyeliaan tahun lepas & 0 & 0 & 33 & 12.3 & 102 & 38.1 & 99 & 36.9 & 34 & 12.7 & 3.50 & 93 & .868 \\
\hline Resolusi mesyuarat pemegang saham tahun lepas & 0 & 0 & 31 & 11.6 & 101 & 37.7 & 113 & 42.2 & 23 & 8.6 & 3.48 & 94 & .809 \\
\hline Glosari atau istilah & 3 & 1.1 & 27 & 10.1 & 105 & 39.2 & 108 & 40.3 & 25 & 9.3 & 3.47 & 95 & .841 \\
\hline Piagam jawatankuasa lain & 1 & .4 & 44 & 16.4 & 98 & 36.6 & 98 & 36.6 & 27 & 10.1 & 3.40 & 96 & .891 \\
\hline Teks ucapan atau pembentangan & 4 & 1.5 & 49 & 18.3 & 100 & 37.3 & 89 & 33.2 & 26 & 9.7 & 3.31 & 97 & .931 \\
\hline
\end{tabular}

Skala: $1=$ Sangat Tidak Penting 2=Tidak Penting 3=Agak Penting 4=Penting 5=Sangat Penting $\mathrm{K}=$ Kedudukan S.P.=Sisihan Piawai

Bagi menjawab persoalan berkaitan tahap kepentingan item bagi dimensi pembentangan, responden dikehendaki memberi maklum balas terhadap 58 item. Pandangan responden diukur dengan menggunakan skala likert 5 mata yang mana 1 mewakili sangat tidak penting dan 5 bermaksud sangat penting. Jadual 5 menunjukkan kepentingan item dalam dimensi pembentangan berdasarkan nilai min. Hasil kajian mendapati 52 item yang tersenarai dalam dimensi pembentangan dikategorikan sebagai item yang penting (iaitu min melebihi 3.50) untuk menggambarkan tahap kepentingan dimensi kandungan dalam PKMI (Ho \& Wong, 2001; Ali Khan \& Ismail, 2008; Ali Khan \& Ismail, 2010; Ali Khan \& Ismail, 2012b). Daripada 52 item tersebut, lapan item boleh dikategorikan sebagai item yang sangat penting (iaitu min melebihi 4.00).

Daripada 58 item, lapan item yang mencapai skor min pada tahap sangat penting yamg mana sepuluh teratas terdiri daripada laporan tahunan dalam format PDF $(\min =4.18)$, masa muat turun laman web syarikat (kurang 10 saat) $(\min =4.10)$, pautan kepada laman web utama $(\min =4.08)$, hiperpautan ada di dalam laporan tahunan $(\min =4.06)$, pautan kepada senarai kandungan $(\min =4.04)$, hiperpautan kepada analisis kewangan $(\min =4.04)$, alamat $\mathrm{e}-$ mel boleh dihubungi terus $(\min =4.02)$, dan keupayaan muat turun laporam $(\min =4.02)$. Hasil kajian ini bertentangan dengan dapatan kajian Ali Khan dan Ismail (2010) dan Ali Khan dan Ismail (2012b) yang menunjukkan bahawa item pelaporan masa muat turun laman web syarikat kurang daripada 10 saat adalah item pelaporan yang paling penting bagi dimensi pembentangan.

Manakala, 52 item yang tersenarai dalam dimensi kandungan dikategorikan sebagai item yang penting yang mana sepuluh daripadanya ialah data kewangan dalam format pemprosesan (contoh Excel) $(\min =3.98)$, penggunaan 
teknologi multimedia $(\min =3.96)$, sempadan atau batasan jelas laporan tahunan $(\min =3.90)$, kemungkinan pertukaran format mudah untuk dicetak $(\min =3.90)$, format laporan sesuai untuk pengiraan $(\min =3.89)$, pengguna boleh muat turun laporan tahunan lengkap mengikut seksyen $(\min =3.89)$, maklumat kewangan lebih daripada satu kadar mata wang (contoh UK£ dan US\$) $(\min =3.89)$, butang seterusnya, sebelumnya navigate sequentially $(\min =3.87)$, pengguna boleh muat turun maklumat kewangan lebih daripada satu format $(\min =3.87)$ dan enjin pencarian dalaman $(\min =3.85)$.

Setelah mendapat maklum balas daripada pengguna penyata kewangan, sejumlah 52 item daripada 58 item dengan skor kepentingan minimum sebanyak 3.50 (sama seperti dalam kajian Ho \& Wong, 2001; Ali Khan \& Ismail, 2008; Ali Khan \& Ismail, 2010; Ali Khan \& Ismail, 2012b) digunakan sebagai asas bagi mengukur indeks PKMI bagi dimensi pembentangan.

Jadual 5 Pandangan keseluruhan kepentingan item bagi dimensi pembentangan

\begin{tabular}{|c|c|c|c|c|c|c|c|c|c|c|c|c|c|}
\hline \multirow[t]{2}{*}{ Item pelaporan } & \multicolumn{2}{|c|}{1} & \multicolumn{2}{|c|}{2} & \multicolumn{2}{|c|}{3} & \multicolumn{2}{|c|}{4} & \multicolumn{2}{|c|}{5} & \multirow[t]{2}{*}{ Min } & \multirow[t]{2}{*}{$\mathbf{K}$} & \multirow[t]{2}{*}{ S.P. } \\
\hline & No. & $\%$ & No. & $\%$ & No. & $\%$ & No. & $\%$ & No. & $\%$ & & & \\
\hline Laporan tahunan dalam format PDF & 0 & 0 & 5 & 1.9 & 44 & 16.4 & 117 & 43.7 & 102 & 38.1 & 4.18 & 1 & .768 \\
\hline $\begin{array}{l}\text { Masa muat turun laman web syarikat (kurang } 10 \\
\text { saat) }\end{array}$ & 0 & 0 & 13 & 4.9 & 46 & 17.2 & 109 & 40.7 & 100 & 37.3 & 4.10 & 2 & .855 \\
\hline Pautan kepada laman web utama & 0 & 0 & 5 & 1.9 & 51 & 19.0 & 129 & 48.1 & 83 & 31.0 & 4.08 & 3 & .755 \\
\hline Hiperpautan ada di dalam laporan tahunan & 0 & 0 & 12 & 4.5 & 50 & 18.7 & 117 & 43.7 & 89 & 33.2 & 4.06 & 4 & .835 \\
\hline Pautan kepada senarai kandungan & 1 & .4 & 7 & 2.6 & 50 & 18.7 & 132 & 49.3 & 78 & 29.1 & 4.04 & 5 & .785 \\
\hline Hiperpautan kepada analisis kewangan & 0 & 0 & 9 & 3.4 & 52 & 19.4 & 126 & 47.0 & 81 & 30.2 & 4.04 & 6 & .795 \\
\hline Alamat e-mel boleh dihubungi terus & 1 & .4 & 8 & 4.0 & 55 & 20.5 & 125 & 46.6 & 79 & 29.5 & 4.02 & 7 & .809 \\
\hline Keupayaan muat turun laporan & 0 & 0 & 8 & 3.0 & 69 & 25.7 & 100 & 37.3 & 91 & 34.0 & 4.02 & 8 & .848 \\
\hline Pautan kepada paparan utama (bahagian atas) & 1 & .4 & 5 & 1.9 & 58 & 21.6 & 134 & 50.0 & 70 & 26.1 & 4.00 & 9 & .767 \\
\hline $\begin{array}{l}\text { Data kewangan dalam format pemprosesan (contoh } \\
\text { Excel) }\end{array}$ & 1 & .4 & 14 & 5.2 & 53 & 19.8 & 121 & 45.1 & 79 & 29.5 & 3.98 & 10 & .859 \\
\hline Penggunaan teknologi multimedia & 2 & .7 & 8 & 3.0 & 61 & 22.8 & 124 & 46.3 & 73 & 27.2 & 3.96 & 11 & .829 \\
\hline Sempadan atau batasan jelas laporan tahunan & 0 & 0 & 10 & 3.7 & 68 & 25.4 & 129 & 48.1 & 61 & 22.8 & 3.90 & 12 & .789 \\
\hline $\begin{array}{l}\text { Kemungkinan pertukaran format mudah untuk } \\
\text { dicetak }\end{array}$ & 0 & 0 & 12 & 4.5 & 68 & 25.4 & 124 & 46.3 & 64 & 23.9 & 3.90 & 13 & .814 \\
\hline Format laporan sesuai untuk pengiraan & 2 & .7 & 11 & 4.1 & 64 & 23.9 & 128 & 47.8 & 63 & 23.5 & 3.89 & 14 & .834 \\
\hline $\begin{array}{l}\text { Pengguna boleh muat turun laporan tahunan } \\
\text { lengkap mengikut seksyen }\end{array}$ & 1 & .4 & 15 & 5.6 & 64 & 23.9 & 121 & 45.1 & 67 & 25.0 & 3.89 & 15 & .858 \\
\hline $\begin{array}{l}\text { Maklumat kewangan lebih daripada satu kadar } \\
\text { mata wang (UK£ \& US\$) }\end{array}$ & 1 & .4 & 17 & 6.3 & 63 & 23.5 & 117 & 43.7 & 70 & 26.1 & 3.89 & 16 & .880 \\
\hline $\begin{array}{lll}\text { Butang seterusnya/sebelumnya navigate } \\
\text { sequentially }\end{array}$ & 0 & 0 & 9 & 3.4 & 75 & 28.0 & 126 & 47.0 & 58 & 21.6 & 3.87 & 17 & .785 \\
\hline $\begin{array}{l}\text { Pengguna boleh muat turun maklumat kewangan } \\
\text { lebih daripada satu format }\end{array}$ & 0 & 0 & 14 & 5.2 & 64 & 23.9 & 133 & 49.6 & 57 & 21.3 & 3.87 & 18 & .804 \\
\hline Enjin pencarian dalaman & 1 & .4 & 12 & 4.5 & 75 & 28.0 & 118 & 44.0 & 62 & 23.1 & 3.85 & 19 & .839 \\
\hline $\begin{array}{l}\text { E-mel terus hiperpautan kepada hubungan dengan } \\
\text { pelabur }\end{array}$ & 1 & .4 & 11 & 4.1 & 73 & 27.2 & 127 & 47.4 & 56 & 20.9 & 3.84 & 20 & .811 \\
\hline Laporan tahunan dalam format HTML & 1 & .4 & 16 & 6.0 & 64 & 23.9 & 135 & 50.4 & 52 & 19.4 & 3.82 & 21 & .823 \\
\hline $\begin{array}{l}\text { Pengguna boleh membandingkan dan menganalisis } \\
\text { stok secara perbandingan atau prestasi lain di } \\
\text { dalam skrin yang sama }\end{array}$ & 1 & .4 & 13 & 4.9 & 78 & 29.1 & 117 & 43.7 & 59 & 22.0 & 3.82 & 22 & .842 \\
\hline Keadaan berwaspada terhadap e-mel & 1 & .4 & 17 & 6.3 & 75 & 28.0 & 115 & 42.9 & 60 & 22.4 & 3.81 & 23 & .870 \\
\hline Maklum balas dalam talian & 1 & .4 & 16 & 6.0 & 73 & 27.2 & 127 & 47.4 & 51 & 19.0 & 3.79 & 24 & .832 \\
\hline Laporan tahunan dalam format pelbagai & 1 & .4 & 20 & 7.5 & 75 & 28.0 & 110 & 41.0 & 62 & 23.1 & 3.79 & 25 & .896 \\
\hline $\begin{array}{l}\text { Servis perkhidmatan maklumat pelabur dalam } \\
\text { talian }\end{array}$ & 0 & 0 & 20 & 7.5 & 68 & 25.4 & 132 & 49.3 & 48 & 17.9 & 3.78 & 26 & .827 \\
\hline Satu klik maklumat hubungan dengan pelabur & 1 & .4 & 20 & 7.5 & 65 & 24.3 & 133 & 49.6 & 49 & 18.3 & 3.78 & 27 & .844 \\
\hline Mesyuarat tahunan & 0 & 0 & 21 & 7.8 & 70 & 26.1 & 123 & 45.9 & 54 & 20.1 & 3.78 & 28 & .856 \\
\hline $\begin{array}{l}\begin{array}{l}\text { Kalkulator pelaburan boleh didapati (contoh } \\
\text { kalkulator dividen) }\end{array} \\
\end{array}$ & 4 & 1.5 & 16 & 6.0 & 67 & 25.0 & 132 & 49.3 & 49 & 18.3 & 3.77 & 29 & .869 \\
\hline Satu klik siaran akhbar atau berita & 0 & 0 & 16 & 6.0 & 78 & 29.1 & 129 & 48.1 & 45 & 16.8 & 3.76 & 30 & .801 \\
\hline $\begin{array}{l}\text { Pengguna boleh melanggan pengumuman umum } \\
\text { melalui e-mel }\end{array}$ & 1 & .4 & 20 & 7.5 & 74 & 27.6 & 121 & 45.1 & 52 & 19.4 & 3.76 & 31 & .864 \\
\hline Terdapat teks hiperpautan & 1 & .4 & 16 & 6.0 & 91 & 34.0 & 102 & 38.1 & 58 & 21.6 & 3.75 & 32 & .876 \\
\hline $\begin{array}{l}\text { Kandungan dalam penyemak lewa berbeza } \\
\text { (Internet Explorer \& Netscape) }\end{array}$ & 2 & .7 & 17 & 6.3 & 83 & 31.0 & 110 & 41.0 & 56 & 20.9 & 3.75 & 33 & .883 \\
\hline
\end{tabular}




\begin{tabular}{|c|c|c|c|c|c|c|c|c|c|c|c|c|c|}
\hline \multirow[t]{2}{*}{ Item pelaporan } & \multicolumn{2}{|c|}{1} & \multicolumn{2}{|c|}{2} & \multicolumn{2}{|c|}{3} & \multicolumn{2}{|c|}{4} & \multicolumn{2}{|c|}{5} & \multirow[t]{2}{*}{ Min } & \multirow[t]{2}{*}{$\mathbf{K}$} & \multirow[t]{2}{*}{ S.P. } \\
\hline & No. & $\%$ & No. & $\%$ & No. & $\%$ & No. & $\%$ & No. & $\%$ & & & \\
\hline $\begin{array}{l}\text { Hiperpautan kepada data dalam laman web pihak } \\
\text { ketiga }\end{array}$ & 1 & .4 & 22 & 8.2 & 79 & 29.5 & 107 & 39.9 & 59 & 22.0 & 3.75 & 34 & .904 \\
\hline $\begin{array}{l}\text { Perkhidmatan menukar data pendaftaran saham } \\
\text { dalam talian }\end{array}$ & 1 & .4 & 16 & 6.0 & 79 & 29.5 & 128 & 47.8 & 44 & 16.4 & 3.74 & 35 & .816 \\
\hline Maklumat atau laman bantuan & 1 & .4 & 15 & 5.6 & 86 & 32.1 & 117 & 43.7 & 49 & 18.3 & 3.74 & 36 & .834 \\
\hline $\begin{array}{l}\text { Pengguna mempunyai pilihan muat turun (hitam } \\
\text { putih atau warna) }\end{array}$ & 3 & 1.1 & 28 & 10.4 & 65 & 24.3 & 111 & 41.4 & 61 & 22.8 & 3.74 & 37 & .962 \\
\hline Muat turun plug in on spot & 1 & .4 & 15 & 5.6 & 90 & 33.6 & 112 & 41.8 & 50 & 18.7 & 3.73 & 38 & .842 \\
\hline $\begin{array}{l}\text { Servis pemegang saham dalam talian boleh } \\
\text { didapati (contoh perubahan alamat dan lain-lain) }\end{array}$ & 3 & 1.1 & 22 & 8.2 & 76 & 28.4 & 111 & 41.4 & 56 & 20.9 & 3.73 & 39 & .922 \\
\hline Pautan dalaman berkaitan dengan kandungan & 0 & 0 & 17 & 6.3 & 86 & 32.1 & 120 & 44.8 & 45 & 16.8 & 3.72 & 40 & .817 \\
\hline $\begin{array}{l}\text { Maklumat alat teknikal (seperti format, saiz muat } \\
\text { turun) }\end{array}$ & 2 & .7 & 19 & 7.1 & 77 & 28.7 & 125 & 46.6 & 45 & 16.8 & 3.72 & 41 & .853 \\
\hline Menu click over & 1 & .4 & 21 & 7.8 & 78 & 29.1 & 122 & 45.5 & 46 & 17.2 & 3.71 & 42 & .854 \\
\hline $\begin{array}{l}\text { Petunjuk teknikal boleh didapati oleh pengguna } \\
\text { (browsers, resolusi skrin) }\end{array}$ & 2 & .7 & 17 & 6.3 & 87 & 32.5 & 114 & 42.5 & 48 & 17.9 & 3.71 & 43 & .861 \\
\hline Penggunaan slaid pembentangan & 2 & .7 & 17 & 6.3 & 88 & 32.8 & 111 & 41.4 & 50 & 18.7 & 3.71 & 44 & .868 \\
\hline Fungsi mencadangkan laman web & 4 & 1.5 & 24 & 9.0 & 72 & 26.9 & 122 & 45.5 & 46 & 17.2 & 3.68 & 45 & .913 \\
\hline Menu tarik turun & 2 & .7 & 22 & 8.2 & 80 & 29.9 & 122 & 45.5 & 42 & 15.7 & 3.67 & 46 & .864 \\
\hline Senarai mel & 1 & .4 & 27 & 10.1 & 84 & 31.3 & 109 & 40.7 & 47 & 17.5 & 3.65 & 47 & .897 \\
\hline Jadual bagi kandungan / peta laman & 1 & .4 & 18 & 6.7 & 94 & 35.1 & 118 & 44.0 & 37 & 13.8 & 3.64 & 48 & .816 \\
\hline Hubungi terus kepada webmaster & 2 & .7 & 31 & 11.6 & 78 & 29.1 & 119 & 44.4 & 38 & 14.2 & 3.60 & 49 & .896 \\
\hline Imej grafik & 2 & .7 & 33 & 12.3 & 78 & 29.1 & 112 & 41.8 & 43 & 16.0 & 3.60 & 50 & .925 \\
\hline Persidangan & 1 & .4 & 27 & 10.1 & 97 & 36.2 & 108 & 40.3 & 35 & 13.1 & 3.56 & 51 & .857 \\
\hline Penggunaan kerangka & 1 & .4 & 26 & 9.7 & 95 & 35.4 & 120 & 44.8 & 26 & 9.7 & 3.54 & 52 & .813 \\
\hline Gambar bergerak (contoh JAVA) & 6 & 2.2 & 41 & 15.3 & 72 & 26.9 & 113 & 42.2 & 36 & 13.4 & 3.49 & 53 & .981 \\
\hline Flashes & 5 & 1.9 & 42 & 15.7 & 86 & 32.1 & 103 & 38.4 & 32 & 11.9 & 3.43 & 54 & .955 \\
\hline Buku notis & 1 & .4 & 33 & 12.3 & 107 & 39.9 & 107 & 39.9 & 20 & 7.5 & 3.42 & 55 & .815 \\
\hline Fail video & 6 & 2.2 & 46 & 17.2 & 87 & 32.5 & 98 & 36.6 & 31 & 11.6 & 3.38 & 56 & .974 \\
\hline Bilik berbual (chat room) & 7 & 2.6 & 43 & 16.0 & 102 & 38.1 & 85 & 31.7 & 31 & 11.6 & 3.34 & 57 & .967 \\
\hline Fail suara & 5 & 1.9 & 60 & 22.4 & 89 & 33.2 & 84 & 31.3 & 30 & 11.2 & 3.28 & 58 & .994 \\
\hline
\end{tabular}

Skala: $1=$ Sangat Tidak Penting 2=Tidak Penting 3=Agak Penting 4=Penting 5=Sangat Penting $\mathrm{K}=$ Kedudukan S.P.=Sisihan Piawai

Sebagai kesimpulan, berpandukan pandangan dan maklum balas daripada pengguna penyata kewangan, sejumlah 92 item daripada 97 item dikenal pasti sebagai asas pengukuran indeks PKMI bagi dimensi kandungan. Manakala, sejumlah 52 item daripada 58 item dikenal pasti sebagai asas pengukuran indeks PKMI bagi dimensi pembentangan.

Secara keseluruhannya, sejumlah 144 item daripada 155 item dikenal pasti sebagai asas pengukuran untuk mengetahui tahap PKMI bagi syarikat yang tersenarai di Bursa Malaysia. Kajian menggunakan skor kepentingan minimum min sebanyak 3.50 (sama seperti Ho \& Wong, 2001; Ali Khan \& Ismail, 2008; Ali Khan \& Ismail, 2010; Ali Khan \& Ismail, 2012b) digunakan sebagai asas (cut-off point) bagi mengukur indeks PKMI. Dapatan kajian ini tidak konsisten dengan kajian Ali Khan dan Ismail (2012b) yang mendapati sejumlah 87 item daripada 155 item yang boleh digunakan dalam dimensi kandungan dan pembentangan bagi indeks PKMI menurut pandangan penyedia penyata kewangan. Dapatan ini menggambarkan bahawa pengguna penyata kewangan memerlukan lebih banyak item pelaporan dalam laman web syarikat bagi membantu mereka membuat keputusan peniagaan dan pelaburan.

\subsection{KESIMPULAN}

Kajian ini bertujuan untuk mengkaji kepentingan item pelaporan berkaitan PKMI dengan mengadaptasikan pandangan pengguna penyata kewangan. Selain itu, pemilihan item pelaporan turut dilihat sebagai berpotensi menjadi kayu pengukur tahap pelaporan sesebuah syarikat yang mempraktikkan PKMI. Hasil kajian mendapati lima item pelaporan terpenting bagi dimensi kandungan ialah penyata pendapatan tahun semasa, penyata aliran tunai tahun semasa, kunci kira-kira tahun semasa, laporan tahunan (teks penuh) tahun semasa, dan laporan juruaudit tahun semasa. Manakala, lima item pelaporan terpenting bagi dimensi pembentangan pula ialah laporan tahunan dalam format PDF, masa muat turun laman web syarikat (kurang 10 saat), pautan kepada laman web utama, hiperpautan ada di dalam laporan tahunan, dan pautan kepada senarai kandungan.

Hasil kajian ini memberikan input yang amat berguna dalam membina senarai semakan indeks PKMI. Kajian ini juga membangunkan instrumen penyelidikan untuk mengukur tahap PKMI dengan menggunakan dua dimensi utama iaitu kandungan dan pembentangan. Instrumen ini dibangunkan dengan mengambil kira kesemua item yang relevan dalam dimensi kandungan, pemasaan, teknologi dan sokongan 
pengguna yang dibina oleh penyelidik lepas. Indeks pelaporan yang dibentuk daripada instrumen ini diharapkan menjadi alat pengukuran yang lebih bersifat menyeluruh dan bersepadu. Berdasarkan sorotan literatur, usaha yang amat terhad dijalankan oleh pengkaji terdahulu untuk mendapatkan pandangan penyedia penyata kewangan dalam pembinaan senarai semakan indeks PKMI.

Hasil kajian ini perlu dipertimbangkan secara berhati-hati memandangkan beberapa limitasi yang ada. Pertamanya, hasil kajian ini menggunakan sistem penskoran wajaran bagi mengetahui kepentingan item PKMI bagi dimensi kandungan dan dimensi pembentangan. Kajian pada masa akan datang boleh dilakukan dengan menggabungkan kedua-dua teknik (sistem penskoran wajaran dan bukan wajaran) untuk mengetahui tahap PKMI. Kedua, hasil kajian ini berpandukan maklum balas daripada pengguna penyata kewangan. Kajian pada masa akan datang boleh dilakukan dengan mendapatkan pandangan balas daripada penyedia penyata kewangan. Seterusnya, skor yang diberikan oleh setiap golongan responden dan dijalankan ujian statistik untuk membandingkan pandangan kedua-dua golongan tersebut. Kajian sebegini dijangka akan memberi sumbangan yang lebih bermakna kepada pihak pengurusan syarikat dan pihak yang berkepentingan mengenai kepentingan item PKMI dalam laman web syarikat untuk sesiapa sahaja yang berminat untuk melabur di Bursa Malaysia bagi membuat keputusan perniagaan dan pelaburan yang rasional, lebih menyeluruh dan bermakna.

Setakat pengetahuan penyelidik yang terbatas, kajian ini merupakan antara kajian awal yang mengkaji pandangan pengguna penyata kewangan terhadap kepentingan item PKMI. Hasil kajian diharap menjadi pencetus kepada kajian lanjutan berkaitan PKMI bukan sahaja di Malaysia, tetapi di negara lain khususnya dari segi pembuktian secara empirikal. Penyelidik turut berharap impak kajian ini dapat meningkatkan kesedaran masyarakat ilmu (seperti penyedia, pengguna, pengamal, industri, penggubal undang-undang, pembuat dasar, penggubal piawaian perakaunan, penyelidik dan badan profesional) terhadap praktis PKMI.

Hasil kajian menunjukkan bahawa sejumlah 144 item daripada 155 item dikenal pasti boleh digunakan untuk mengetahui tahap PKMI bagi syarikat yang tersenarai di Bursa Malaysia. Kajian pada masa hadapan boleh dilakukan dengan membuat perbandingan tahap PKMI antara negara-negara yang berbeza. Seterusnya, kebanyakan syarikat menyediakan maklumat korporat menerusi Internet hanya dalam bahasa Inggeris, yang mana tidak semua para pengguna maklumat perakaunan dan bakal pelabur (dalam konteks persekitaran di Malaysia) mahir dengan bahasa tersebut. Oleh yang demikian, syarikat di Malaysia seharusnya menyediakan maklumat korporat menerusi Internet dalam dua bahasa iaitu Inggeris dan Melayu. Secara keseluruhan, kajian ini mengutarakan persoalan kajian yang baru dan membentangkan bukti secara empirikal menurut perspektif negara yang sedang membangun. Kajian lanjutan boleh menggunakan metodologi dan perspektif alternatif bagi membantu untuk memahami isu yang dibincangkan.

\section{PENGHARGAAN}

Penulis ingin mengucapkan ribuan terima kasih kepada penilai artikel ini yang banyak memberi input yang berguna bagi menambahbaik penjelasan yang sedia ada. Penulis turut ingin merakamkan ucapan terima kasih di atas maklum balas yang membina semasa sesi pembentangan di International Conference on Applied Business Research (ICABR) $2011 \mathrm{di}$
Zon Regency Hotel, Stulang, Johor pada 29-31 Disember 2011 anjuran Mendel University in Brno, Chezh Republic dan 2012 International Summer Conference on Asia Pacific Business Innovation and Technology (APBITM) di Genting International Convention Center, First World Hotel, Kuala Lumpur pada 1-3 Julai 2012 anjuran Asia Pacific Business Innovation and Technology Management Society. Penulis turut mengucapkan ribuan terima kasih kepada Puan Norhayati binti Haji Salleh di atas pengeditan artikel ini. Kajian mendapat pembiayaan daripada Universiti Teknologi Malaysia melalui Skim Geran Jangka Pendek (Staf Akademik Baru dengan PhD) Vot No. 77972 dan Skim Geran Universiti Penyelidikan (GUP) Vot No. Q J130000.2629.02J80.

\section{Rujukan}

Abdelsalam, O.H., Bryant, S.M., and Street, D.L. 2007. An Examination of Comprehensiveness of Corporate Internet Reporting Provided by London-Listed Companies. Journal of International Accounting Research. 6(2): 1-33.

Abdelsalam, O.H., and El-Masry, A. 2008. The impact of board independence and ownership structure on the timeliness of corporate internet reporting of Irish-listed companies. Managerial Finance. 34(12): 907-918.

Abdelsalam, O.H., and Street, D.L. 2007. Corporate governance and the timeliness of corporate internet reporting by U.K. listed companies. Journal of International Accounting, Auditing and Taxation. 16: 111 130.

Abdul Hamid, F.Z. 2005. Malaysian companies' use of the internet for investor relations. Corporate Governance: The International Journal of Business in Society. 5(1): 5-14.

Abdul Hamid, F.Z., and Md Salleh, M.S. 2005. The Determinants of the Investor Relations Information in the Malaysian Companies' Website. Corporate Ownership \& Control. 3(1): 173-185.

Abdul Hamid, F.Z., Md Salleh, M.S., and Mohamad, R. 2006. A survey of the use of internet for the investor relations by the Malaysian and Singapore firms. Unpublished Research Report. Sintok, Malaysia: Universiti Utara Malaysia, School of Accounting.

AbuGhazaleh, N.M., Qasim, A., and Haddad, A.E. 2012. Perceptions and attitudes toward corporate website presence and its use in investor relatins in the Jordanian context. Advances in Accounting. 28(1): 1-10.

Al-Htaybat, K. 2011. Corporate online reporting in 2010: a case study in Jordan. Journal of Financial Reporting \& Accounting. 9(1): 5-26.

Al-Htaybat, K., Alberti-Alhtaybat, L.V., and Hutaibat, K.A. 2011. Users' Perceptions on Internet Financial Reporting Practices in Emerging Market: Evidence from Jordan. International Journal of Business and Management. 6(9): 170-182.

Al Arussi, A.S., Selamat, M.H., and Mohd Hanefah, M. 2009. Determinants of financial and environmental disclosures through the internet by Malaysian companies. Asian Review of Accounting. 17(1): 59-76.

Ali Khan, M.N.A. 2010. Pelaporan Kewangan menerusi Internet: Indeks, Tahap Pelaporan dan Faktor Penentunya. Unpublished $\mathrm{PhD}$ Dissertation: Universiti Utara Malaysia, Sintok, Kedah.

Ali Khan, M.N.A., and Ismail, N.A. 2008. Kepentingan Item Pelaporan Kewangan Menerusi Internet: Satu Kajian Awal. Paper presented at International Accounting and Business National Management Conference (NAMAC) 2008, Terengganu, December 13-14, 2008.

Ali Khan, M.N.A. and Ismail, N.A. 2009a. Internet Financial Reporting in Malaysia: Factors, Pros and Cons. Accountants Today. 22(2): 28-31.

Ali Khan, M.N.A and Ismail, N.A. 2009b. Dimensi Pelaporan Kewangan Menerusi Internet. International Journal of Management Studies. 16(1): 75-96.

Ali Khan, M.N.A. and Ismail, N.A. 2010. Kajian Awal terhadap Kepentingan Item Pelaporan Kewangan Menerusi Internet di Malaysia. International Journal of Management Studies. 17(2): 205-230.

Ali Khan, M.N.A. and Ismail, N.A. 2011a. The Use of Disclosure Indices in Internet Financial Reporting Research. Journal of Global Business and Economics. 3(1): 157-173.

Ali Khan, M.N.A., and Ismail, N.A. 2011b. The Level of Internet Financial Reporting of Malaysian Companies. Asian Journal of Accounting and Governance. 2: 27-39.

Ali Khan, M.N.A., and Ismail, N.A. 2011c. Pelaporan Kewangan Menerusi Internet: Tinjauan Kajian Lepas. International Journal of Management Studies. 18(2): 21-52. 
Ali Khan, M.N.A., and Ismail, N.A. 2012a. A Review of E-Financial Reporting Research. Journal of Internet and e-Business Studies. 2012: 16 pages.

Ali Khan, M.N.A., and Ismail, N.A. 2012b. An empirical study on the indexes of internet financial reporting: The case of Malaysia. African Journal of Business Management. 6(5): 2086-2100.

Ali Khan, M.N.A., and Ismail, N.A. 2012c. Users' Perceptions of Various Aspects of Malaysian Internet Financial reporting. Journal of Organizational Management Studies. 2012: 14 pages.

Allam, A., and Lymer, A. 2003. Development in Internet Financial Reporting: Review and Analysis Across Five Developed Countries. The International Journal of Digital Accounting Research. 3(6): 165-199.

Aly, D., Simon, J., and Hussainey, K. 2010. Determinants of corporate internet reporting: evidence from Egypt. Managerial Auditing Journal. 25(2): 182-202.

Ashbaugh, H., Johnstone, K.M., and Warfield, T.D. 1999. Corporate Reporting on the Internet. Accounting Horizons. 13(3): 241-257.

Ayob, A.M. 2005. Kaedah Penyelidikan Sosioekonomi. $3^{\text {rd }}$ ed. Kuala Lumpur: Dewan Bahasa dan Pustaka.

Barako, D.G., Rusmin, R., and Tower, G. 2008. Web communication: An Indonesian perspective. African Journal of Business Management. 2(3): 53-58.

Barsky, N.P., and Catanach, A.H. 2011. Every Manager Can Be an Innovator. Strategic Finance. 93(2): 22-29.

Bonson, E., and Escobar, T. 2002. A Survey on Voluntary Disclosure on the Internet: empirical Evidence from 300 European Union Companies. The International Journal of Digital Accounting Research. 2(1): 27-51.

Bonson, E., and Escobar, T. 2006. Digital reporting in Eastern European: An empirical study. International Journal of Accounting Information System. 7: 299-318.

Boubaker, S., Lakhal, F., and Nekhili, M. 2012. The determinants of webbased corporate reporting in France. Managerial Auditing Journal. 27(2): 126-155.

Bozcuk, A.E. 2012. Internet financial reporting: Turkish companies adapt to change. Managerial Finance. 38(8): 786-800

Celik, O., Ecer, A., and Karabacak, H. 2006. Impact of Firm Specific Characteristics on the Web Based Business Reporting: Evidence from the Companies Listed in Turkey. Problems and Perspectives in Management. 4(3): 100-133.

Chan, W.K., and Wickramasinghe, N. 2006. Using the internet for financial disclosure: the Australian experience. International Journal Electronic Finance. 2(1): 118-150.

Cooke, T.E., and Wallace, R.S.O. 1989. Global Surveys of Corporate Disclosure Practices and Audit Firms: A Review Essay. Accounting and Business Research. 20(77): 47-57.

Curuk, T. 2008. An analysis of the companies' compliance with the EU disclosure requirements and corporate characteristics influencing it: A case of Turkey. Critical Perspectives on Accounting. Retrieved August 6, 2008, from doi:10.1016/j.cpa.2007.05.003.

Davey, H., and Homkajohn, K. 2004. Corporate Internet Reporting: An Asian Example. Problems and Perspectives in Management. 2: 211 227.

Debreceny, R., Gray, G.L., and Rahman, A. 2002. The determinants of internet financial reporting. Journal of Accounting and Public Policy. 21(4-5): 371-394

Despina, A.C., and Demetrios, P.L. 2009. The web-based financial reporting adopted by the listed companies in the Athens Stock Exchange. Journal of Modern Accounting and Auditing. 5(7): 7-20.

Erer, M. 2011. The Impact of Corporate Governance on Internet Financial Reporting: Evidence from Turkey. International Journal of Business Research. 11(3): 26-46.

Ettredge, M., Richardson, V.J., and Scholz, S. 2001. The presentation of financial information at corporate Web sites. International Journal of Accounting Information Systems. 2: 149-168.

Ettredge, M., Richardson, V.J., and Scholz, S. 2002. Dissemination of information for investors at corporate Web sites. Journal of Accounting and Public Policy. 21: 357-369.

Ezat, A., and El-Masry, A. 2008. The impact of corporate governance on the timeliness of corporate internet reporting by Egyptian listed companies. Managerial Finance. 34(12): 848-867.

FASB. 2000. Business reporting research project: Electronic distribution of business reporting information. Steering Committee Report Series. Financial Accounting Standards Board.

Frazer, L., and Lawley, M. 2000. Questionnaire design \& administration. Australia: John Wiley \& Sons.

Gibbins, M., McCracken, S.A., and Salterio, S.E. 2007. The Chief Financial Officer's Perspective on Auditor-Client Negotiations. Contemporary Accounting Research. 24(2): 387-422.
Gowthorpe, C. 2004. Asymmetrical dialogue? Corporate financial reporting via the Internet. Corporate Communications: An International Journal. 9(4): 283-293.

Haniffa, R.M. 1999. Culture, Corporate Governance and Disclosure in Malaysian Corporation. Unpublished $\mathrm{PhD}$ Thesis, University of Exeter, United Kingdom.

Hanifa, M.H., and Ab. Rashid, H. 2005. The Determinants of Voluntary Disclosures in Malaysia: The Case of Internet Financial Reporting. UNITAR E-Journal. 2(1): 22-42.

Hassan, S, Jaaffar, N., Johl, S.K., and Mat Zain, M./N. 1999. Financial reporting on the internet by Malaysian companies: Perceptions and practices. Asia-Pacific Journal of Accounting, 6(2): 299-319.

Henchiri, J.E. 2011. Voluntary web-based disclosures by Moroccan and Tunisian companies. EuroMed Journal of Business. 6(2): 155-173.

Ho, S.S.M., and Wong, K.S. 2001. A study of the relationship between corporate governance structures and the extent of voluntary disclosure. Journal of International Accounting, Auditing \& Taxation. 10: 139-156.

Ho, S.S.M., and Wong, K.S. 2003. Preparers' perceptions of corporate reporting and disclosure. International Journal of Disclosure and Governance. 1(1): 71-81.

Hodge, F.D. 2001. Hyperlinking Unaudited Information to Audited Financial Statements: Effects on Investor Judgements. The Accounting Review. 76(4): 675-691.

Hodge, F., and Pronk, M. 2006. The Impact of Expertise and Investment Familiarity on Investors' Use of Online Financial Report Information Journal of Accounting, Auditing \& Finance. 21(3): 267-292.

Hodge, F.D., Kennedy, J.J., and Maines, L.A. 2004. Does Search-Facilitating Technology Improve the Transparency of Financial Reporting? The Accounting Review. 79(3): 687-703.

Homayoun, S., Abdul Rahman, R., and Bashiri, N. 2011. Internet corporate reporting among public listed companies in Malaysia: An exploratory study. African Journal of Business Management. 5(30): 11863-11873 .

IASC. 1999. IASC Publishers Study of Business Reporting on the Internet. Press Release: International Accounting Standards Committee, 15 November 1999.

Inchausti, B.G. 1997. The influence of company characteristics and accounting regulation on information disclosed by Spanish firms. The European Accounting Review. 6(1): 45-68

Ismail, N.A., and Tayib, M. 2000. Financial Reporting Disclosure on the Internet by Malaysian Public Listed Companies. Akauntan Nasional. 13(10): 28-33.

Ismail, T.H., and Sobhy, N.M. 2009. Determinants of auditors' perceptions of the work needed in the audit of internet-based financial reports in Egypt. Journal of Applied Accounting Research. 10(2): 132-150.

Jaffar, R., Hassan, M.S., and Muhammad, N. 2010. Peranan Etika dalam Pelaporan Maklumat Alam Sekitar di Malaysia. Jurnal Pengurusan. 31: 13-27.

Keliwon, K., and Aziz, K.A. 2005. Web financial reporting in Malaysia. The current stage. Proceedings of International Conference on E-Commerce 2005, Kuala Lumpur. 59-65.

Kelton, A.S., and Yang, Y. 2005. The impact of corporate governance on Internet financial reporting. Working Paper, Department of Accounting and Information Management, University of Tennessee.

Kelton, A.S., and Yang, Y. 2008. The impact of corporate governance on Internet financial reporting. Journal of Accounting and Public Policy. 27(1): $62-87$.

Khadaroo, M.I. 2005a. Business reporting on the internet in Malaysia and Singapore: A comparative study. Corporate Communications: An International Journal. 10(1): 58-68.

Khadaroo, M.I. 2005b. Corporate reporting on the internet: some implication for the auditing profession. Managerial Auditing Journal. 20(6): 578591.

Khan, T. 2006. Financial Reporting Disclosure on the Internet: An International Perspective. Unpublished doctoral dissertation, Victoria University, Footscray Park, Victoria, Australia.

$\mathrm{Ku}$ Ismail, K.N.I., and Chandler, R. 2005. Perceptions of Professional Investors in Malaysia on the Usefulness of Quarterly Financial Reports. Jurnal Pengurusan. 24: 105-124.

Ku Ismail, K.N.I., and Chandler, R. 2007. Quarterly Financial Reporting: A Survey of Malaysian Users and Preparers. Research in Accounting in Emerging Economies. 7: 53-67.

Leng, T.L., Lazar, J., and Othman, R. 2007. Adoption of Financial Reporting Standards (FRSs): Impact on Malaysian Companies. Unpublished research report. Malaysian Accountancy Research and Education Foundation.

Lybaert, N. 2002. On-Line Financial Reporting: An Analysis of the Dutch Listed Firms. The International Journal of Digital Accounting Research 2(4): 195-234. 
Lymer, A., and Tallberg, A. 1997. Corporate Reporting and the Internet - a survey and commentary on the use of the $W W W$ in corporate reporting in the UK and Finland. Paper presented at the Annual Congress of the European Accounting Congress, Graz, Austria.

Malhotra, P., and Makkar, R. 2012. A Study of Corporate Web Reporting Practices in India. The IUP Journal of Corporate Governance. XI(1): 7 19.

Marston, C., and Polei, A. 2004. Corporate reporting on the Internet by German companies. International Journal of Accounting Information System. 5: 285-311.

McDonald, R., and Lont, D. 2001, September. Financial Reporting on the Web - A 2001 Review. Chartered Accountants Journal. 64-68.

Mirshekary, S., and Saudagaran, S.M. 2005. Perceptions and characteristics of financial statement users in developing countries: Evidence from Iran. Journal of International Accounting, Auditing and Taxation. 15: 33-54.

Mohamad, R., Saad, S., Ismail, S.A., and Abdul Rahman, A. 2006. Malaysian Corporate Website: A survey of Web Characteristics. Paper presented at International Conference on ICT for the Muslim World (ICT4M) 2006, Kuala Lumpur, November 21-23, 2006.

Mohd Hanafi, S.R., Kasim, M.A., Ibrahim, M.K., and Hancock, D.R. 2009. Business Reporting on the Internet: Development of a Disclosure Quality Index. International Journal of Business and Economics. 8(1) 55-79.

Mohd Hanafi, S.R., Kasim, M.A., Ibrahim, M.K., and Othman, R. 2008 Internet Business Reporting: Development of a Disclosure Quality Index (IBRQ). Paper presented at International Accounting and Business Conference (IABC) 2008, The Puteri Pan, Johor Bahru, Johor, August 18-19, 2008.

Mohd Isa, R. 2006. Graphical Information in Corporate Annual Report: A Survey of Users and Preparers Perception. Journal of Financial Reporting \& Accounting. 4(1): 39-60.

Momany, M.T., and Shorman, S.A. 2006. Web-based Voluntary Financial Reporting of Jordanian Companies. International Review of Business Research Papers. 2(2): 127-139.

Moradi, M., Salehi, M., and Arianpoor, A. 2011. A study of the reasons for shortcomings in establishment of internet financial reporting in Iran. African Journal of Business Management. 5(8): 3312-3321.

Nurunnabi, M., and Hossain, M.A. 2012. The voluntary disclosure of Internet financial reporting (IFR) in an emerging economy: a case of digital Bangladesh. Journal of Asia Business Studies. 6(1): 17-42.

Oppenheim, A.N. 1992. Questionnaire Design, Interviewing and Attitude Measurement. (New ed.). London, UK: Pinter.

Oyelere, P., Laswad, F., and Fisher, R. 2003. Determinants of Internet Financial Reporting by New Zealand Companies. Journal of International Financial Management and Accounting. 14(1): 26-61.
Pervan, I, and Sabljic, M. 2011. Voluntary Internet Financial Reporting in Croatia - Analysis of Trends and Influential Factors. The Business Review. 17(2): 213-219.

Poon, Park-Look, Li, D., and Yu, Y.T. 2003. Internet Financial Reporting. Information Systems Control Journal. 1: 1-3.

PricewaterhouseCoopers. 2002. Market Readiness for Disclosure-Based Regulation, Highlights from survey on the readiness for the Malaysian Market Capital participants for DBR. Kuala Lumpur: Securities Commission.

Seetharaman, A., and Subramaniam, R. 2005/2006. Navigating the Web of Financial Reporting. European Business Forum. Winter(23): 51-54.

Sekaran, U. 2003. Research Methods For Business A Skill Building Approach. $4^{\text {th }}$ ed. USA: John Wiley \& Sons, Inc.

Spanos, L. 2006. Corporate reporting on the internet in a European emerging capital market: the Greek case.

Sriram, R.S. and Laksmana, I. 2006. Corporate Web Site Reports: Some Evidence on Relevance and Usefulness. Information Resources Management Journal. 19(3): 1-17.

Standen, C.J.V. 1998. The usefulness of the Value Added Statement in South Africa. Managerial Finance. 24(11): 44-59.

Topalian, A. 2003. Experienced reality The development of corporate identity in the digital era. European Journal of Marketing. 37(7/8) $1119-1132$.

Trabelsi, S., Labelle, R., and Laurin, C. 2004. CAP Forum on E-Business: The Management of Financial Disclosure on Corporate Websites: A Conceptual Model. Canada Accounting Perspectives. 3(2): 235-259.

Turel, A. 2010. The Expectation Gap in Internet Financial Reporting: Evidence from an Emerging Capital Market. Middle Eastern Finance and Economics. 8: 94-107.

Uyar, A. 2012. Determinants of corporate reporting on the internet An Analysis of companies listed on the Istanbul Stock Exchange (ISE) Managerial Auditing Journal. 27(1): 87-104.

Wallace, R.S.O. 1988. Corporate financial reporting in Nigeria. Accounting and Business Research. 18(72): 352-362.

Wallace, R.S., Kamal, N., and Mora, A. 1994. The Relationship between the Comprehensiveness of Corporate Annual Reports and Firms Characteristics in Spain. Accounting and Business Research. 25(97): 41-53.

Wilmshurst, T.D., and Frost, G.R. 2000. Corporate environmental reporting A test of legitimacy theory. Accounting, Auditing Accountability Journal. 13(1): 10-25.

Xiao, J.Z., Yang, H., and Chow, C.W. 2004. The determinants and characteristics of voluntary Internet-based disclosures by listed Chinese companies. Journal of Accounting and Public Policy. 23: 191-225. 